\title{
Conflict Minerals and Supply Chain Due Diligence: An EXPloratory Study OF Multi-Tier SupPly Chains
}

\author{
Hannes Hofmann \\ Institute for Supply Chain Management (ISCM), EBS Business School, EBS University for Business \\ and Law, Burgstraße 5, 65375 Oestrich-Winkel, Germany
}

\section{Martin C. Schleper}

German Graduate School of Management and Law (GGS), Bildungscampus 2, 74076 Heilbronn, Germany, martin.schleper@nottingham.ac.uk

\section{Constantin Blome}

School of Business, Management and Economics, University of Sussex, Jubilee Building 302, Falmer, Brighton BN1 9SL, UK, c.blome@ sussex.ac.uk

Hannes Hofmann, Martin C. Schleper, and Constantin Blome have contributed an equal amount to the manuscript

Published online ahead of printing

Citation:

Hofmann, H., Schleper, M.C., \& Blome, C. (2015). Conflict minerals and supply chain due diligence: An explanatory study of multi-tier supply chains. Journal of Business Ethics, in print. 


\section{Abstract:}

As recently stakeholders complain about the use of conflict minerals in consumer products that are often invisible to them in final products, firms across industries implement conflict mineral management practices. Conflict minerals are those, whose systemic exploitation and trade contribute to human right violations in the country of extraction and surrounding areas. Particularly supply chain managers in the Western world are challenged taking reasonable steps to identify and prevent risks associated with these resources due to the globally dispersed nature of supply chains and the opacity of the origin of commodities. Supply chain due diligence (SCDD) represents a holistic concept to proactively manage supply chains reducing the likelihood of the use of conflict minerals effectively. Based on an exploratory study with 27 semi-structured interviews within five European industries we provide insights into patterns of implementation, key motivational factors, barriers and enablers, and impacts of SCDD in mineral supply chains. Our results contribute to both theory and practice as we provide first insights to SCDD practices and make recommendations for an industry-wide implementation of SCDD. Altogether, this study provides the basis for future theory testing research in the context of SCDD and conflict mineral management.

\section{Introduction}

Human rights violations and social problems are highly prevalent in business practices despite the success story of corporate social responsibility $(\mathrm{CSR})^{1}$ in the last two decades (Arnold, 2010). In fact, social conflicts and human rights abuses caused by companies are rather rule than exception and thus, the United Nations' Working Group on the issue of human rights and transnational corporations and other business enterprises (2014, p. 3) recently reported to the General Assembly an urgent need "[...] to strengthen legal and policy frameworks to prevent and protect against human rights abuses by business enterprises".

\footnotetext{
We would like to sincerely thank the two anonymous reviewers for their constructive feedback that helped us to improve the manuscript significantly.

${ }^{1}$ Although the term is often used as a synonym and sometimes also as an umbrella term for many related concepts such as business ethics, corporate accountability, corporate citizenship, corporate sustainability, etc. (cp. Scherer and Palazzo, 2011), in line with McWilliams and Siegel (2001, p. 117), we define CSR as "actions that appear to further some social good, beyond the interests of the firm and that which is required by law". "Social good" in this context does include ethical and environmental issues, too. Moreover, we will follow the extended notion of CSR, "political CSR", as discussed within the background section. For a detailed overview of CSR definitions see Dahlsrud (2008).
} 
Due to increasing business process outsourcing and globally dispersed production facilities, social problems and human rights violations are no longer only intraorganizationally rooted, but also often occur in companies' supply chains (Grimm et al., 2011), which makes them a complex and vital challenge for supply chain managers as the example of Apple has shown. In 2012 Apple admitted a human rights problem within its supply chains and a failure of its supplier monitoring system (Foley, 2012), best illustrated by its key supplier Foxconn that turned out to be a constant source of tremor due to questionable labor conditions (e.g., Duhigg and Barboza, 2012; Xu and Li, 2013).

Besides the negative effects of conflict minerals on those that are directly affected by it, human rights violations also bear an enormous reputational risk for companies allegedly associated with conflict minerals. Key stakeholders (e.g., consumers, mass media, employees) expect companies to behave responsibly (Parmar et al., 2010) and have become intolerant of those not fulfilling their human rights expectations (Dawkins and Lewis, 2003). Consequently, firms that are located downstream in the supply chain and that are more visible to stakeholders are particularly threatened by social supply chain problems.

New frameworks and regulations such as the UK Bribery Act, the recent UK Modern Slavery Act, the California Transparency in Supply Chains Act, the above mentioned UN Guiding Principles for Business \& Human Rights, or the Brazilian National Pact for the Eradication of Slave Labour strive to eliminate opacity in global supply chains by advocating a proactive and multi-tier logic (Sedex, 2013). Simultaneously, companies are more and more beginning to understand the importance of managing indirect (sub-)suppliers as many financial, operational, and sustainable problems lie beyond the closest tier levels of suppliers (Tachizawa and Wong, 2014).

The recent debate among practitioners and scholars concerning the topic of so-called conflict minerals or 3TG - tin, tantalum, tungsten, and gold from conflict areas such as the Democratic Republic of Congo (DRC) Region - illustrates the importance of social and human rights issues in management practice as well as the emerging need to react to social conflicts. Conflict minerals are those, whose systematic exploitation and trade in a context of conflict contribute to, benefit from or result in the commission of serious violations of human rights, violations of international humanitarian law or violations amounting to crimes under international law (Global Witness, 2014). Being a scourge for a whole region, conflict minerals do not only involve child and slave labor, but also generate considerable funds for armed groups (Gold et al., 2015). Thus, they contribute to the continuation or outbreak of violent conflict and undermine national endeavors towards development, good governance, and the rule of law. In 
this regard, conflict minerals are similar to "blood diamonds" that have widely attracted media attention in the 1990s and 2000s. Conflict minerals, however, are processed in many different components throughout various industries and hence have a high overall impact on business (Rotter et al. 2014).

In recent attempts to cope with conflict minerals, both international and national initiatives like the Dodd-Frank Wall Street Reform and Consumer Protection Act (Dodd-Frank Act) or the OECD Due Diligence Guidance for Responsible Supply Chains of Minerals from ConflictAffected and High-Risk Areas (OECD Guidance) demand supply chain managers to verify purchased goods as "conflict-free" or to implement measures in order to better manage these problems. As a reaction firms have begun to apply several governance mechanisms to avoid adverse effects of conflict mineral sourcing. For instance, based on the Electronic Industry Citizenship Coalition (EICC) code of conduct many firms in the consumer electronics industry have published conflict mineral statements either separately on their web page or within their own (supplier) code of conduct. Exemplarily, LG requires its suppliers to "evaluate the origin or source of their materials throughout their supply chains to verify that they have not been obtained through any illegal form of mining (e.g., materials obtained from the Democratic Republic of Congo)" (LG, 2013).

However, the mere transfer of responsibilities upstream the supply chain apparently will not stop the trade with conflict minerals, notably due to two reasons: On the one hand, globalization has created governance gaps in a sense that companies are able to abuse human rights without being sanctioned by independent third parties (Ruggie, 2008; Scherer and Palazzo, 2007). This gap results in a non-allocation of responsibility that makes the problem of human rights abuses and social conflicts within dispersed supply chains very likely to endure, particularly without collaborative approaches to remedy these deficiencies (Rotter et al., 2014). On the other hand, conflict minerals usually originate from globally diverse deposits and are difficult to track within components and manufactured products. This is the case because these minerals are mostly mixed with minerals of different origin and added to metal alloys. Consequently, although the share of these minerals in single end products is negligible, they are prevalent in numerous products and commodities.

Together, these circumstances leave downstream firms nearly incapable of detecting risks associated with conflict minerals. Hence, the topic of conflict minerals becomes one of supply chain management rather than of individual companies' legal or compliance divisions alone. What is needed is effective and supply chain wide mechanisms of traceability and due diligence that allow firms to take individual and collective responsibility as parts of supply chains. As 
Ruggie (2008, p. 17) states: "To discharge the responsibility to respect [human rights] requires due diligence. This concept describes the steps a company must take to become aware of, prevent and address adverse human rights impacts."

In the context of mineral supply chains, due diligence represents a holistic concept that aims at providing a chain of custody tracking from mine to export at country level, regional tracking of mineral flows through the creation of a database on their purchases, independent audits on all actors in the supply chain, and a monitoring of the whole mineral chain by a mineral chain auditor (Bleischwitz et al., 2012). In this sense, due diligence transcends conventional risk management approaches that usually focus on the prevention of direct impacts on the core business activities of companies. Moreover, due diligence focuses on a maximum of transparency as an end itself while risk management is always directed towards the end of averting direct damages. However, besides the Dodd-Frank Act and the OECD Guidance, there is still a gap in due diligence practices as international norms are just emerging (Sarfaty, 2015).

Our research is exploratory in nature and aims at finding first patterns of supply chain due diligence (SCDD) implementation in practice. Furthermore, we expect specific enablers and barriers for SCDD to be in place that differ within particular firms and industries. The novelty of the concept and its emerging significance for all kind of industries lead to the question, what kind of effects and consequences SCDD might have for companies once it is implemented.

By following these paths of research, we state recommendations for an industry-wide implementation of SCDD, explore the new concept, and provide the basis for future theory testing research. Accordingly, our research questions are the following:

(1) Which patterns of SCDD implementation do exist in practice?

(2) What are enablers and barriers of SCDD implementation?

(3) What is the expected impact of SCDD?

To answer these questions, we conducted 27 semi-structured exploratory interviews with European firms from five different industries, most prevalent for the use of conflict minerals such as 3TG: aerospace and defense, technical hardware, jewelry, automotive, and electronics. Thus, our study includes a cross-sectional multi-tier approach including Original Equipment Manufacturers (OEMs), typical first tier suppliers (component manufacturers), and second- to third-tier suppliers (metal traders, metal processors, and refineries) (cp. Figure 1).

**** Please insert Figure 1 about here $* * * *$ 
The remainder of the article is structured as follows: After providing a profound background on social conflicts inherent in mineral supply chains together with approaches to manage these in section two, we introduce our implementation framework in section three. The subsequent section describes the applied methods followed by the results of our analysis in section five. After a discussion of the findings with managerial implications and an outlook on avenues for further research in the sixth section, the last section concludes this article.

\section{Background}

While the emergence of concepts such as CSR and in particular sustainability was accompanied by a research focus on the environmental impacts of supply chain management, more recently the discussion about social issues in supply chains has gained a new quality and made it as a top priority among NGOs, the media and ultimately, customers (Klassen and Vereecke, 2012).

In particular, the classical CSR concept, understood as "taking actions that appear to further some social good, beyond the interests of the firm and that which is required by law" (McWilliams and Siegel, 2001, p. 117) is incrementally extended by stakeholders towards a responsibility of firms for wrongdoings that hardly fall into their direct sphere of influence (Amaeshi et al., 2008) leading to new concepts, such as political CSR (Scherer and Palazzo, 2006; 2007; 2011).

Political CSR has gained attention particularly due to the work of Matten and Crane (2005) as well as Scherer and Palazzo $(2007 ; 2011)$ and the literature has been increasingly expanded since (e.g., Crane et al., 2008; Mäkinen and Kourula, 2012; Rotter et al., 2014; Whelan, 2012). In its essence, political CSR differs from traditional CSR aspects in its demand to transcend not only the initial role of businesses that seeks besides profit maximization also to further social goods but also to fill gaps that resulted from eroding international and national regulations caused by globalization (Scherer and Palazzo, 2007). From this perspective, companies, in particular internationally acting ones with global supply chains, have begun to take on statelike roles in order to partially fill the gap left behind by failed states and missing supra- and international regulative frameworks (Matten and Crane, 2005). Consequently, firms are increasingly required to track and manage sources for social conflicts in their supply chains, particularly upstream. As background for our study, the following paragraph summarizes important literature on social problems in supply chains and passes on to a detailed perspective on how these issues contextualize in mineral supply chains. Subsequently, the applicability of established supply chain governance mechanisms is depicted, closing with a reflection on the SCDD concept. 


\subsection{Social problems in supply chains}

Multinational corporations operating in developing countries are particularly prone to social risks due to a lack of national regulation in developing countries and efficient firm initiatives to ensure a basic level of safety and decent working conditions (Locke, 2013). As a result, social problems linked to human rights abuses (e.g., forced and child labor, excessive working hours, discrimination) and omissions in providing safe and healthy working conditions (limited or no access to fresh water, no fire protection, missing emergency exits, etc.) remain structural problems within various industries. Besides conflict minerals, among the most prominent and upsetting examples are unsafe working conditions in the textile industry (e.g., the Ali garment factory fire in Karachi, Pakistan where more than 300 factory workers died in 2012 due to locked doors and windows) or incidents of forced and child labor in the food and crop industry (exemplified by West-African cocoa and coffee producers, Thai prawn-trawlers, Kazakh tobacco plantations, or Uzbek cotton fields (Bhat, 2013; Griffin, 2014; Kramer, 2010; Manzo, 2005).

Furthermore, industries extracting natural resources such as oil, gas, metals, and minerals are regularly shattered by events related to labor accidents and human rights abuses (Silva and Jacinto, 2012). Upcoming with the topic of blood diamonds, for the first time the Western public had conceived a direct link between their own consumption behavior and the promotion of social problems in conflict-laden countries. In the blink of an eye it became clear that Western luxury in terms of jewelry and particularly diamonds comes at the cost of developing countries suffering from long-lasting civil wars; ironically often directly caused by Western colonization. Not least this increased attention for social problems led to the emergence of celebrated initiatives such as the Kimberley-Process which attempted to generate a certification scheme and to foster transparency in the process of diamond extraction. However, the image of this initiative had rapidly crumbled as it constantly refused to address the clear links between diamonds, violence, and tyranny in Zimbabwe, Côte d'Ivoire, and Venezuela (Garrett and Lintzer, 2010; Panikkar and Brugge, 2007; Rhode, 2014; Global Witness, 2011). As a result, issues of blood diamonds are still prevalent today (Perry, 2012).

Recently, conflict minerals receive more attention in theory and practice due to the unintended consequences they cause at the origin of supply chains. For example, in DRC and the adjacent area, despite the end of the civil war in 2002, in 2008 it was estimated that still 45,000 people were dying every month and that the finances of conflict minerals and the fight for these resources were a central driver for this. As Sullivan and Atama (2010, p. 1) suggest: "With only a few guns and shovels, local warlords can establish themselves as a group that 
must be reckoned with, financing their own growth into a militia powerful enough to demand a seat at the table in negotiations and eventually a position in the army-from where they can continue to profit from the minerals trade." These armed groups control 12 of the 13 major mines in DRC (BSR, 2010) and received significant funds not only by direct control over these mines, but also by taxing transport and trade combined with paying poor wages, or employing children as miners (for a detailed description see Epstein and Yuthas, 2011). Overall, armed groups receive 90 percent of the profits from conflict minerals whereas workers receive very limited pay (Prendergast \& Lezhnev, 2009). It is also important to note that financial resources attract genocidaires like the Democratic Forces for the Liberation of Rwanda (FDLR) which receives their major income from these sources. Moreover, these groups initiate not only gun conflict, rape, and slavery, but it is also obvious that central governments in these countries are not able to terminate these conflicts as their military is also often involved in these mafia-like structures illustrating a looming gap in governance.

\subsection{Conflict minerals as a catalyst for social problems in supply chains}

In the case of conflict mineral supply chains, most social problems are settled around raw material extracting activities within the sourcing country (cp. Figure 1). Due to specific geological conditions - deposits of tin, tantalum, and tungsten are often too small to be amendable by large-scale industrial enterprises - mining within conflict and high risk regions is mainly pursued as artisanal and small scale mining (ASM) (Garrett and Lintzer, 2010).

However, ASM poses many problems for those people pursuing it. In general, governments of conflict areas do not recognize the legality of ASM. Thus, small scale miners are operating illegally, or at best in a legal grey area, which leaves them without any governmental protection and thus open to exploitation by armed groups (BSR, 2010).

Aside from these legality problems, small scale miners suffer from missing health and safety standards and financial drawbacks. The majority of workers subsists on less than $\$ 5$ per day, which often locks them in debt to local traders and strongmen (Prendergast and Lezhnev, 2009). Moreover, small scale miners are forced to buy an annual digger card from extra-governmental authorities, charging \$25 which many cannot afford (Bleischwitz et al., 2012).

ASM is highly work intensive and increasingly attracts low-skilled urban families. Thus, children are usually part of the ASM workforce (André and Godin, 2014). In most instances, ASM is controlled by armed groups that seek benefits from trading conflict minerals. Once such groups control a mine, they put workers under extortion and physical harm (Kristof, 2010). Hence, profits from conflict minerals skimmed by armed groups are not contributing to 
improved living standards within the sourcing regions (i.e., better schools and health care) but contrarily impair these (Prendergast and Lezhnev, 2009).

Finally, subsequent export related activities are susceptible to social problems as well: Large parts of transportation to and within neighboring countries of conflict areas are controlled by armed groups which usually require payments either in taxes or mineral shares (OECD, 2013). Local consolidators and exporters are often paid in advance by international traders. Thus, although it is fairly easy to determine the origin of the minerals at this stage (and to avoid sourcing from conflict regions and mines), these exporters and consolidators do not require proof of origin but rely only on verbal checks instead (Prendergast and Lezhnev, 2009). This allows traders in surrounding countries to buy conflict minerals and to mix them with legally exported and produced minerals (Epstein and Yuthas, 2011). The fact that most of these traders rely on the protection of officers in security services (police or military) with which they keep close ties even intensifies this flawed process; thereby establishing a climate of repression and real threat of violence.

When it comes to tracing conflict minerals in supply chains back to their sources, the starting point of the metal supply chain (mostly smelters) is mainly cited as the critical link to do so (Young et al., 2010). Once the mineral ore is refined into metal it becomes impossible to distinguish material with and without conflict minerals. Indeed, adequate records of mineral origin are rarely kept or passed to new owners (Prendergast and Lezhnev, 2009; Rotter et al., 2014). In subsequent downstream stages, the minerals are refined and the metal is used to create components such as capacitors (tantalum), solder (tin), specialty metals (tungsten), or jewelry (gold). Afterwards, product manufacturers or original design manufacturers use these components to assemble compound products (e.g., hard drives, semiconductors, or screens) which are then finally assembled by OEMs or product companies and sold to end customers. Yet, particularly along these latter steps, social problems caused by conflict minerals rarely occur.

\subsection{Managing social problems in minerals supply chains}

Firms apply many different measures and processes in order to gather and share relevant information on social problems within their supply chains. The main goal of all these different processes is to increase transparency and to gain as much knowledge as possible about suppliers and the circumstances under which particular goods and services are produced. Yet, as there are many different partners involved in globally dispersed multi-tier supply chains, OEMs and other large downstream firms face enormous difficulties in collecting the required information 
(Epstein and Yuthas, 2011). Lower suppliers often either do not have the information available or are reluctant to share it as they fear competitive drawbacks.

Although the management of social problems in mineral supply chains is a matter of supply chain risk management in a broader sense, some important differences need consideration. Firms try to achieve conflict-free mineral supply chains from a very early stage on by focusing mainly on practices that focus on collecting relevant information about lower suppliers. Yet, this risk identification phase is only one component in risk management approaches besides risk analysis, risk evaluation, and risk treatment (ISO 31000, 2009). The common understanding of supply chain risk management deviates even more, as its main purpose is to build and maintain resilient supply chains and first and foremost to prevent supply disruptions (Kleindorfer and Saad, 2005), which is not the primary goal in the context of managing mineral supply chains with regard to social problems.

Hence, the potential set of measures for the management of social problems in mineral supply chains is diminished down to few viable processes linked to risk identification that are prevalent among firms: certification schemes, chains of custody, traceability, and due diligence processes (Bouslah et al., 2010; Doorey, 2011; Epstein and Yuthas, 2011; Fasterling and Demuijnck, 2013; Jaffee, 2010; Morali and Searcy, 2013). Table 1 provides an overview of these concepts and illustrates their main features for risk identification.

**** Please insert Table 1 about here $* * * *$

Due diligence originally describes a versatile investigation and inspection of the financial operations of a company and is usually applied prior to mergers and acquisitions (Sinkin and Putney, 2014). Yet, more and more the concept is also applied to implement regulatory frameworks, such as, the UNHCR Guiding Principles on Business and Human Rights (Fasterling and Demuijnck, 2013) or the Dodd-Frank Act. The latter is particularly important in the context of SCDD as it sets a new landmark: The Dodd-Frank Act provides an obligation for firms that file reports with the United States Securities and Exchange Commission (SEC) to screen their extended supply chains for conflict minerals. Roughly at the same time as the DoddFrank Act, a collaborative, government-backed, multi-stakeholder initiative was developed: the OECD Guidance. Both, OECD Guidance and the Dodd-Frank Act aim to "provide a chain of custody tracking from mine to export at country level, regional tracking of mineral flows through the creation of a database on their purchases, independent audits on all actors in the supply chain and a monitoring of the whole mineral chain by a Mineral Chain Auditor" 
(Bleischwitz et al., 2012, p. 27). However, these two initiatives differ with regard to the expected outcome: While the Dodd-Frank Act requires corporations to be conflict-free in terms of their products, the main purpose of the OECD Guidance is to provide comprehensive recommendations for companies so that they thoroughly respect human rights when sourcing minerals or metals (OECD, 2013)

Hence, the OECD Guidance is mostly based on the logic of SCDD processes and recommends the following five process steps to firms: (1) Establishment of strong company management systems, (2) identification and assessment of supply chain risk, (3) design and implementation of a strategy to respond to risk, (4) carrying out independent third-party audits of SCDD, and (5) reporting on SCDD (OECD, 2013). When following these broad advises, firms are supposed to increase the overall transparency along their supply chains from raw material extraction over refinement and component production until the end consumer. In this sense, SCDD enables the trace-back of conflict minerals until their origin and represents a promising approach in light of interconnected social conflicts and actors in minerals supply chains.

In the following section, we investigate the theoretical processes of implementing SCDD, thereby building the foundation of our empirical investigation.

\section{Theoretical framework of SCDD implementation}

In order to clarify aspects of how SCDD processes are implemented within organizations, we base our study on the original research model of Litz (1996) and adapt it according to our field of interest and towards a more dynamic perspective (cp. Figure 2). This model is a means to ground our research in literature, to guide and focus our investigation, and to base our findings on theory. Opposed to purely grounded research we build our study on this framework as well as on further related literature.

The CSR topics under scrutiny (i.e., conflict minerals regulations and SCDD processes) are just recently emerging and have already attracted high public and scholarly attention. Yet, despite the vast general recognition of CSR within business practice, it has still not been investigated - neither empirically nor theoretically - which implementation mechanisms support the corporate success of CSR implementation (Lindgreen and Swaen, 2010). Thus, only few studies focused on the dynamic and practical aspects of the process of installing CSR within organizations (e.g., Dobele et al., 2014; Lindgreen et al., 2009), which explicitly calls for more research to close this gap. In this context, Litz' (1996) framework suits our research interests 
particularly well as it allows us to conceptually structure our explanatory and inductively conducted study.

$$
\text { **** Please insert Figure } 2 \text { about here } * * * *
$$

Based on a critique of the resource based view of the firm (RBV) Litz (1996, p. 1355) highlighted the need to extend RBV in terms of CSR aspects due to a "commensurate lack of attention dedicated to conceptualizing the resource-worthiness of a corporation's social and ethical response capabilities". In its initial form, RBV has claimed that organizational performance is mainly shaped and influenced by an organization's individual resources and capabilities which can be assets, information and knowledge, human capital, firm attributes, and so on (Barney, 1991). However, Litz (1996) and others (e.g., McWilliams and Siegel, 2001) emphasized the need to incorporate CSR capabilities (i.e., "to perceive, assess, and respond to the social and ethical dimensions of daily corporate life" (Litz, 1996, p.1355)) as these can also render competitive advantage for firms.

Hence, referring to Kuhn's $(1963 ; 1974)$ original three stage model of companies' adaptive behavior, Litz (1996) integrated insights from CSR literature into an enriched three stage model of adaptive behavior. This model states three specific stages which organizations undergo if they are to adequately react to social and ethical issues within their daily corporate environment: (1) the phase of perceiving a stimulus; (2) the phase of deliberation; and (3) performance outcomes (Litz, 1996).

Yet, as CSR illustrates a dynamic business environment, resulting in constantly changing competitive and regulative frameworks and continuously altered stakeholder expectations - the emergence of conflict minerals serves as a distinguished example of this - we follow Reuter et al. (2010) in their assessment to interpret Litz (1996) in terms of dynamic capabilities in place of RBV. Dynamic capabilities are a "firm's capacity to integrate, build and reconfigure internal and external resources using organizational processes to respond to changes in the competitive environment and to design new value creating strategies" (Reuter et al., 2010, p. 48).

As the expected OECD Guidance generates a first general awareness for the conflict mineral topic among many European firms that are not subject to the Dodd-Frank Act, we intentionally used the model of adaptive behavior to find the reasons "why" and "how" the OECD Guidance are implemented within participating organizations and "what" particularly outcomes they either expect or already have realized. 
Hence, in order to frame the study accurately, in the following we will explain each of these three stages in more detail by transferring them to our specific context.

(1) Stimuli perception: We assume that companies require a perception of certain stimuli in order to consider the OECD Guidance and SCDD processes to become part of their corporate behavior. Whelan (2012) emphasizes the need for more clarity in the range of companies' motivations for decision-making in CSR. With its voluntary character, the OECD Guidance leaves its implementation open to firms. Yet, as previous studies have shown different motivations and lines of argumentation exist for firms to follow new guidelines or not (e.g., Logsdon and Wood, 2005; Schleper and Busse, 2013; Short and Toffel, 2010; Wright and Rwabizambuga, 2005). Getting a better grasp of the internal and external reasons that motivate organizations to invest upfront in the implementation of voluntary initiatives, (e.g., code of conducts and new standards), marks the starting point of our study and enlightens the first phase of corporate success of CSR implementation.

(2) Response selection: According to the second step in the model of adaptive behavior, we expect a selection of response to take place within companies that implement SCDD processes. Of course, this central step exhibits a path dependency as there may be different strategies and options for firms how to respond to these pressures, depending on their specific resources, experiences within CSR contexts, characteristics of supply chains, the particular supply chain position, and so on. Thus, we assume firms' existent dynamic capabilities to be most important as dynamic capabilities are crucial for designing new strategies. As dynamic capabilities “determine the speed at, and degree to which, the firm's particular resources can be aligned and realigned to match the requirements and opportunities of the business environment" (Teece, 2012, p. 1395), it is this internal deliberation and selection process that enables a company to successfully exploit the implementation of the OECD Guidance by developing an own understanding of the SCDD process according to its already existing routines and capabilities.

(3) Performance outcomes: Finally, in order to allow for an advanced analysis, we shed light on the performance outcomes, too. Although we expect in many cases a close link between the prospected benefits of implementing the OECD Guidance and SCDD processes and the initial motivation of companies to do so, the path dependency of the dynamic capability concept requires us to also investigate this last step of the adaptive behavior model.

\section{Methods}

An inductive multiple case study approach was selected to explore why and how companies implement SCDD in conflict minerals supply chains and what the expected performance 
outcomes will be. This approach appeared to be adequate for the following four reasons: (1) To our knowledge, research on both, due diligence outside of financial contexts and conflict minerals is in its early stages (cp. Sarfaty, 2015) with only few published articles (e.g., Fasterling and Demuijnck, 2013; Muchlinski, 2012; Rotter et al., 2014; Sarfaty, 2015); (2) SCDD on conflict minerals requires investigating multiple actors along various tiers of the supply chain. Therefore, the issue at hand constitutes a complex research problem rendering it to naturalistic inquiry in which insights are induced by interpretative means (Lincoln and Guba, 1985); (3) Case study research is well-suited to study complex phenomena from different angles and to compare various organizational situations (Eisenhardt, 1989; Yin, 1981; 2014); (4) The triangulation of data from multiple sources allows for mitigation of the social desirability bias which is inherent in the topic at stake (Crane, 1999). Table 2 provides an overview of the measures taken to address the concerns regarding validity and reliability throughout the course of our research.

**** Please insert Table 2 about here $* * * *$

\subsection{Case selection and data collection}

Besides an extant literature review, preliminary expert interviews provided the foundations for developing the sampling frame. In order to gain in-depth insights into SCDD implementation, we followed the notion of Gerring (2007) and employed a diverse case selection technique. The study addresses five major industries which are impacted by conflict mineral issues: the automotive, aerospace and defense, electronics, technical hardware, and jewelry industry. Due to the novelty of the SCDD concept within the domain of the OECD countries and in light of an upcoming EU regulation (Global Witness, 2015), our study focuses on European firms.

Furthermore, the sample mirrors the multi-tier setting of conflict minerals supply chains: OEMs are based far downstream with great end-consumer proximity. Thus, OEMs may be directly targeted by stakeholder requirements on SCDD (e.g., Dodd-Frank Act, customer requirements, or NGO pressure). Component manufacturers exemplify small- or medium sized first-tier suppliers. Typically, these firms are only concerned with conflict minerals to the extent their direct customers demand it. Finally, metal refiners, smelters, and traders are positioned at lower tiers and interact directly with raw-material extracting firms. Thus they can provide firsthand insights into the conditions in conflict and high-risk areas. In addition, metal refiners, smelters, and traders face enormous regulatory pressure as they are considered to be importers of conflict minerals and related metals to the European market. Hence, they represent the last 
stage in which due diligence processes can effectively be assured by collecting, disclosing, and verifying information on a mineral's origin and chain of custody (European Commission, 2014). However, we did not include raw-material extracting firms from the DRC due to our focus on firms based in Europe as well as limited access to these sources.

The companies within our dataset are headquartered in eight European countries, with strongest representation from Germany, UK, and France. They represent both, SMEs and large size companies ( 5 million EUR to 75 billion EUR in annual revenues) and amount to an overall sales volume of 347 billion EUR. Table 3 provides an overview of the participating companies.

**** Please insert Table 3 about here $* * * *$

Primary data was collected through a series of in-depth interviews with executives and managers in 27 companies. Respondents are mainly senior managers who are working in procurement or sustainability departments. However, our sample is also complemented by conflict mineral specialists, CEOs, and risk managers, thereby showcasing the variety of expertise that is needed to thoroughly tackle the issue of conflict minerals.

All semi-structured interviews were conducted in February/March 2014 via telephone. At the same time, other information about the companies and their specific initiatives, such as companies' website contents, CSR-reports, company codes of conduct and supplier policies, and third party certifications were also collected in order to lay the ground for later data triangulation and to strengthen and verify the use of the interview data (Dykstra et al., 2003; Gibbert et al., 2008; Miles and Huberman, 1994; Seale, 2000). On average, each interview lasted 60 minutes and all interviews were jointly conducted by the same two researchers. Reliability was accounted by means of an interview protocol including information on the interview procedure and context information (e.g., date of the interview and where and how archival data was collected). Finally, a case database stored individual notes on the spoken dialogue, transcripts from the interviews, and content from other sources of information (Gibbert et al., 2008; Yin, 2014).

\subsection{Coding}

The extracted data was analyzed by applying qualitative content analysis (Miles and Huberman, 1994) and was led both by codes grounded in data and concepts established in related research (Eisenhardt, 1989; Strauss and Corbin, 1990; Yin, 2014). Thus, in structural equivalence to Litz' (1996) model of adaptive behavior we screened each case for stimulus, response, and 
performance outcome of SCDD adaption. In a first round of coding we used rather descriptive codes for the depiction of the interview content (open coding). Next, we pursued axial coding and gradually transformed descriptive codes into more abstract ones which were then condensed and related to each other. Furthermore, similar codes were grouped into themes and overarching dimensions. After each researcher individually coded each case, we discussed the obtained codes to increase inter-rater reliability (Pagell and Krause, 2005). In cases in which reviewers disagreed with each other the coding was repeated and discussed in order to reach a joint conclusion. In the very small number of cases where no similar interpretation could be found the respective codes were not further included in the final analysis.

\section{Analysis and results}

The following section presents the results of our exploratory study. We start by introducing patterns of SCDD implementation, as they lay the ground for recognizing relationships between these very patterns, stimuli, enablers and barriers, as well as expected impacts.

\subsection{Patterns of supply chain due diligence implementation}

Firms apply different patterns of SCDD implementation that vary across industries. For instance, while especially large firms from both electronics and automotive industry apply sophisticated approaches, surprisingly, jewelry firms are rather lagging in terms of SCDD implementation. This is particularly interesting, as one might expect jewelry firms to be notably aware of conflict resources' risk potential. As Janssen et al. (2014) find, there are specific characteristics of luxury products that conclude in the acceptance of responsible luxury. Hence, there should be a bigger learning effect particularly in the jewelry industry.

In the course of our overall analysis we specifically found patterns that are based on compliance, commitment, and analytical measures (cp. Table 4) resulting from firms' individual practices to identify, trace, and remove conflict minerals from their supply chains. Table 5 illustrates groups of firms whose practices are predominantly allocated to a certain pattern. However, it needs to be emphasized that these three patterns are not mutually exclusive. Firms do not necessarily implement only one of these patterns. Rather, they apply mixed practices depending on their individual stage of SCDD implementation.

**** Please insert Table 4 and 5 about here $* * * *$ 
Compliance practices are prevalent across all five industries. For this implementation pattern measures such as issuing codes of conduct, stating a conflict-free policy, or fostering ethical sourcing of conflict minerals via contractual provisions are characteristic. Compliance practices are usually enforced very strictly. Firms following this approach attempt to reorganize their supplier portfolios to focus on cooperation with large and experienced companies, whereas suppliers that do not adhere to compliance regimes are immediately replaced, if possible. As such practices require a dominant market position and a high degree of power over supply chain partners, compliance measures are usually implemented by larger firms downstream the supply chain. Locke et al. (2009) highlight that compliance-oriented approaches are mainly based on negative rules such as pressures, regular monitoring, and severe sanctions. In sum, these compliance patterns aim at setting up strict principles to govern conflict mineral management upstream.

Commitment measures contrarily, comprise cooperative practices and firms that actively engage and support their suppliers towards fulfilling requirements for due diligence. We found this pattern particularly to be present in firms from the automotive, electronics, and technical hardware industries. These commitment-oriented approaches focus on positive values such as learning, collaboration, analysing root causes to problems, as well as incentives and mutual respect (Locke et al., 2009). This includes mainly efforts for awareness raising, staff education, and practical support. For instance, at a kick-off meeting, Engine A has raised the issue of conflict minerals as a collective responsibility of the whole supply chain and assisted its suppliers to provide required documentation. Although commitment is practiced only occasionally, those firms who apply this measure belong to the largest actors within their respective industries. Thus, we assume that commitment represents an innovative approach the strategic potential of which has not yet been widely recognized among firms.

Analytical practices finally are common across all five industries but strongest among automotive companies. Firms that rely on analytical practices intend to gain detailed insights into the composition of sourced products. For instance, they assess the chemical structure of their product portfolio to obtain comprehensive and detailed information regarding the content of conflict minerals in sourced products. Based on this assessment, critical suppliers are identified and engaged to provide insights into sourcing activities and materials. Other firms identify critical products and suppliers based on a risk assessment. Analytical practices are prevalent at all firm sizes and supply chain positions. Opposed to the compliance patterns, firms applying analytical practices tend to lack supply chain compliance regimes. Thus, analytical practices might represent a preparatory step determining avenues for the compliance pattern. 


\subsection{Stimulus for firm's awareness on conflict minerals and supply chain due diligence}

As a necessary precondition for SCDD implementation, firms' awareness on the issue of conflict minerals needs to be stimulated. Similar to other transparency initiatives (e.g., certifications), due diligence implementation requires internal and external triggers (Bouslah et al., 2010). Institutional theory (DiMaggio and Powell, 1983; Jennings and Zandbergen, 1995; Oliver, 1991; Scott, 1987) offers a theoretical lens to group aspects that trigger firms' implementation of sustainable practices (e.g., Bansal, 2005; Escobar and Vredenburg, 2011; Pedersen and Gwozdz, 2014). Accordingly, normative (professionalization of processes), mimetic (imitation of practices of other successful organizations), or coercive pressures (coercion by powerful actors) stimulate organizations to implement specific practices. Similarly, interviewees revealed regulative (e.g., Dodd-Frank Act), peer (e.g., activities of industry associations), and competitive pressures (e.g., customer requirements) as stimuli for their awareness of conflict minerals. Typically, firms are exposed to several stimuli at the same time. However, based on our interviews we categorize firms according to their most prominent trigger (cp. Table 6).

**** Please insert Table 6 about here $* * * *$

Regulative stimuli represent both enforceable regulation (Dodd-Frank Act) and recommendations on due diligence (OECD Guidance) and are prevalent at the majority of firms across all industries, firm sizes, and supply chain positions. For some firms regulative pressure is a necessary precondition to take up the issue of conflict minerals at all: "We would need an external impulse like the Dodd-Frank Act to deal with these issues and to implement them" (Engine D). Others are required to follow the Dodd-Frank Act as their major customers are based on the US market and thus pass on relevant regulation to their suppliers: "Our main customers are US-based. Thus, they are obliged to follow the Dodd-Frank Act and pass on these requirements to us, their customers" (Aero A). In sum, regulative pressures are not only directly stimulating SCDD implementation within a fixed geographic setting, but may also be pushed upstream and thus indirectly affect geographically dispersed firms.

Peer pressure for firms to take action is caused by rising awareness among a large group of similar companies. Especially in the electronics and jewelry industries peer pressure evolves as industry associations are promoting conflict minerals management, for example, through issuing practical guidance or setting standards: "We have a strong manual containing all industry standards and issues and so we are also certified by the Royal Jewelry Council and we 
are also looking at the sourcing protocols and we try to implement them back into our supplier manual" (Jewel A). Furthermore, informal industry groups were reported to create benchmarks and to provide a forum to discuss problems and best practices of conflict mineral management: "We are using an unofficial benchmarking with the major Swedish industry companies so that we can discuss our problems with each other, find some solutions and so on" (Engine C). As industry standards and benchmarking systems are usually scaled up experiences of pioneering firms, we conjecture that regulative pressures have been present in the first place yielding a critical group of first movers. Thus, peer pressure has to be located adjacent to regulative stimuli.

Competitive stimuli occur, when suppliers are required to follow powerful customers' provisions. For instance, lower tier actors at the refinery and smelter level reported that implementing SCDD was as necessary precondition for entering into business: "We have no choice, all you have to do is to comply, or you just get out of it. And personally ... if I want to continue I have to be compliant" (Aero D). Above all, firms are often not dealing with conflict minerals until required by their customers to do so: "Due diligence at this point needs to be initiated by our customers, asking us to demonstrate if we are meeting the requirements" (Engine E). In sum, competitive stimuli emerge from downstream firms which are already engaged in conflict mineral management and that are striving to shift responsibility upstream.

Based on this explanatory analysis, we identify relationships between the type of stimulus and patterns of implementation (cp. Table 7).

First of all, firms that face regulative pressure choose in most instances compliance-oriented SCDD practices. Both Dodd-Frank Act and OECD Guidance provide extensive assistance on due diligence implementation and thus are likely to determine a sophisticated regime of supplier governance.

Second, peer pressured firms apply each of the three implementation patterns. Yet, it does not surprise that some firms engage in compliance-oriented practices, as peer pressure was characterized as adjacent to regulative stimuli. On the other side, Jewel A and Jewel D rely on analytical practices which are well applicable to their gold-focused activities.

Finally, competitive stimuli elicit mainly analytical practices. On the one hand, competitive stimuli represent urgent requests from key customers. On the other hand, they offer limited guidance on implementing due diligence practices within the upstream supply chain. Thus, firms under competitive pressure might refrain from time-consuming development of novel practices and rely on their already present analytical capabilities instead. 


\subsection{Expected impact and performance of supply chain due diligence}

Implementing SCDD does not only enable firms to track and exclude conflict minerals from their supply chains. It delivers additional impacts on market performance (e.g., compliance and transparency), financial performance (e.g., satisfied customer requirements and reduced risk exposure), and relational assets (e.g., increased awareness and new strategic partnerships) (cp. Table 8).

**** Please insert Table 8 about here $* * * *$

Market performance impacts of due diligence are found at downstream and upstream parts of the mineral supply chain. Electro A states that due diligence enables compliance with regulation but also to "satisfy the information needs of our customers". In addition, market performance impacts of SCDD may also accrue upstream: "The benefits of compliance are primarily two things, one satisfying customers in their expectations and secondly, generally, reputation. [...] We see a lot of benefits to the human rights situation in DRC and neighboring countries" (Engine E). This is in line with many other studies that either show potentially negative effects on reputation due to deficits in suppliers' corporate social performance (e.g., Carter and Jennings, 2004) or that show positive effects due to actively governing CSR topics (e.g., Pedersen and Andersen, 2006). Taken together, market performance impacts of SCDD disseminate at both ends of the supply chain and tend to accrue for the whole supply chain instead of a single firm.

In addition to its impacts on market performance, SCDD implementation contributes to improved financial performance, for example through mitigating costs caused by incurred risks: "Sharing information with suppliers and make suppliers be more open about their supply chains would help us to map potential risks [...] you perhaps can identify certain pitch points within the supply chain where the risk maybe exist. And that might help corporates to protect them in the future by looking more to sourcing opportunities that do not take the forms of risks" (Auto D). Finally, firms expect that market performance will translate directly into financial benefits as Auto B explains: "We are able to demonstrate that our materials or components which are delivered to the OEM are not sourced from conflict- or high-risk areas. We use this as an asset for future tenders". Engine D emphasizes business customers in a similar fashion: 
"Our customers are large OEMs and they want to promote their products to be conflict-free". Eventually, end consumers are perceived to yield cash flows as well: "The main [...] benefit that will be customer goodwill in the US market and we hope that we will soon become conflict free and this would hopefully have a big impact on the US market" (Engine C).

Finally, implementing SCDD involves both actors along the supply chain and stakeholders whose constant dialog generates new strategic networks and alliances (Doorey, 2011) and increases benefits for involved actors. This is also in line with Busse (2016) who points in this direction by identifying collaboration benefits as a positive mediating factor of how changes in sustainability-related conditions at a supplier influence buyers' economic performance by fostering trust. As Carter and Jennings (2002) find, activities of sustainable supply chain management such as SCDD foster a positive reputation of the partner which increases trust and triggers relational benefits (e.g., better resolution of extant problems).

Thus, for Engine A, implementing SCDD has a clear relational impact: "I think it is a program which typically also in the EICC community has strengthened our relationship that I see as a real benefit. It was a program that urged us to work together more closely than we did before. And very active working groups are created, very strong and active networks and very close cooperation. That will have a spin off in later stages, where other legislations or issues are popping up so we have a strong network in the industry based on this approach". One company only affirms relational impacts. Nevertheless they represent a key aspect of implementing supply chain wide due diligence processes which due to the novelty of the issue may have gone unnoticed so far.

Drawing on Table 9, relations between implementation patterns and impacts become apparent. First, compliance-oriented practices are associated with both market performance and financial performance. On the one hand, compliance-oriented practices are built upon regulative and multi-stakeholder based frameworks that aim to manage human rights problems around conflict minerals. Thus, market performance impacts might indicate the successful execution of these frameworks. On the other hand, financial benefits accrue for most compliance-oriented firms, irrespective of size and supply chain position supplementing their profit maximizing orientation.

Second, the commitment pattern leads to market performance, relational assets, and financial performance benefits. Whereas financial performance impacts might point at the complexity reducing effect of coordinated due diligence implementation, market performance impacts exemplify a conjoint approach to improve the upstream human rights situation. 
Finally, analytical practices lead to market performance and financial performance impacts. Market performance impacts of analytical practices are reported especially far upstream at refineries and smelters whereas financial benefits are present at larger downstream firms. Thus, the pinch point of the mineral supply chain - namely smelters and refineries - is under constant pressure to contribute to due diligence systems but is at the same time hardly able to develop sufficient governance measures let alone market-based benefits.

**** Please insert Table 9 about here $* * * *$

\subsection{Enablers and barriers of implementing supply chain due diligence}

Implementing SCDD requires not only several facilitators but also overcoming hurdles. Executives cited several external and internal factors that serve as critical enablers (cp. Table 10). Similarly, hurdles for SCDD implementation may occur internally and externally (cp. Table 11).

**** Please insert Table 10 about here $* * * *$

External tools and support systems enable standardized information exchange between firms which is a central tenet of SCDD (Fasterling and Demuijnck, 2013; New, 2010; Pagell and Wu, 2009). In particular, tools and programs developed by the Conflict Free Sourcing Initiative (CFSI) are facilitating the development of governance systems and information exchange between upstream and downstream actors. Moreover, relying on the CFSI does not only involve using templates but is in fact a trusting relationship and division of labor (i.e., CFSI offers audits of smelters). The International Material Data System (IMDS) is applied in the automotive industry. Relying on that system, Auto D developed a very sophisticated analytical practice to detect conflict mineral-containing products. Likewise, the jewelry industry complimented relevant intelligence tools and expressed willingness to extend their use.

Implementing due diligence along the whole supply chain requires involving multiple geographically dispersed actors and it is mostly the downstream actors' responsibility to push due diligence upstream. Thus, both power and trust are important enablers for compliance, commitment, and analytical practices. For instance, some executives complained that their activities would be more advanced if there would be more leverage on their side.

Another perspective on power is introduced by an executive from the automotive industry. Although his firm is in a dominant position, there is not sufficient leeway to get suppliers 
involved. For some firms, implementing due diligence within the rather unregulated European market is a strategic decision they are reluctant to take as a first mover. Accordingly, regulation presents a trust-building facilitator demanding concerted levels of supply chain transparency among all firms, curtailing concerns of competitive disadvantage (Doorey, 2011), and enabling exchange of confidential information (Hannah, 2005).

As a key internal enabler raising awareness of and commitment to programs on conflict minerals, internal management support was cited. For instance, a clear mission statement from the CEO of Jewel D was critical to set the spirit for a successful conflict minerals campaign.

**** Please insert Table 11 about here ****

As a major external barrier for SCDD implementation, some executives criticize relevant regulation and guidance on conflict minerals for being unclear. For instance central aspects like 'reasonable efforts' (OECD Guidance) are undefined and reliable benchmarks to evaluate firms' activities are not available. Furthermore, regulative frameworks are only focused on the US market. In addition, the Dodd-Frank Act does only target SEC-filing companies. Indeed, Asian or African as well as small or medium sized firms are not obliged to perform due diligence on conflict minerals, thus impeding for example compliance practices of downstream firms.

Another obstacle for due diligence implementation is directly market-driven: some firms are tied to static supplier relationships forcing them to stick with (problematic) suppliers or to even resign from driving a strict conflict minerals policy. A further market-given fact is affirmed by Electro A stating that the number of certified smelters is currently too low in order to facilitate a conflict-free minerals supply chain. If paired with low levels of power, market-driven barriers may leave firms unable to implement sophisticated compliance processes and to stick to the analytical pattern.

In addition to these barriers, firms at all stages of the supply chain struggle with the high complexity of their individual supply chains. Several firms reported a great distance to relevant upstream actors such as smelters and refineries, leaving them incapable of enforcing compliance practices. Furthermore, the products of downstream firms are highly complex impeding a comprehensive analytical fingerprint. However, complexity is not only a downstream issue. Even firms that are supposed to be at arms-length to raw material stages are overstrained to perform analytical practices on multiple actors. The commitment pattern may serve as remedy as its cooperative and coordinated character overcomes complexity issues. 
Furthermore, implementing SCDD could be very costly depending on a firm's supplier portfolio (Fasterling and Demuijnck, 2013). Especially in the upstream supply chain, substantial investments are required to establish fundamental mechanisms. Furthermore, the quality of obtained information strongly depends on the know-how and education within the supply chain.

Overall, complying with all requests for due diligence is a huge administrative burden for small upstream firms. In this regard, firms might outsource compliance requests (e.g., CFSI certification) and apply analytical practices instead to identify the origins of conflict minerals.

$$
\text { **** Please insert Figure } 3 \text { about here } * * * *
$$

\section{Discussion}

The following paragraphs outline the theoretical and managerial implications of our research. Within the theoretical part, SCDD is discussed from a critical-normative as well as a business management perspective (cp. Drebes, 2014) particularly with a focus on how SCDD contributes to the wider field of political CSR. Moreover, we relate our findings to the newly emerging stream of multi-tier supply chain management research (e.g., Mena et al., 2013). As a major managerial contribution, we offer recommendations for industry-wide SCDD implementation. We conclude with a critical discussion of limitations and provide avenues for further research.

\subsection{Theoretical implications}

The social problems linked to conflict minerals are part of a broader discussion on human rights violations and imply an extension of the classical CSR concept to a politically coined one (Whelan, 2012). Caused by the increasing globalization in the last decades, national and international regulations have continuously eroded, leaving behind a tremendous gap in institutional governance instruments and processes (Matten and Crane, 2005; Scherer and Palazzo, 2011), as also perfectly indicated in the conflict mineral case (cp. Rotter et al., 2014).

Starting in the mid of the 2000s, research has actively called for a debate about the role of business entities under these changing circumstances (Matten and Crane, 2005; Walsh, 2005). In light of this discourse, firms are expected to at least partially fill out this regulative gap by taking up responsibilities that traditionally fall within states' spheres of influence (Scherer and Palazzo, 2011). Accordingly, in the conflict minerals context, firms can meet their responsibilities through SCDD. Whelan (2012) states particularly two reasons why the link 
between multinational companies and this new gap is striking and applicable to the conflict mineral context as well: On the one hand, these companies operate in countries and regions that usually fall far behind Western democratic and liberal standards in terms of social and environmental regulations and on the other hand, the normative force of the factual has proven companies to already play important roles in creating new standards, public goods, and international regulative patterns.

In our sample we identify three different patterns of SCDD implementation: analytical, compliance, and commitment. These patterns differ significantly from each other and also reflect distinction in companies' CSR implementation. In case of analytical SCDD implementation, firms merely apply minimum requirements necessitated by stronger supply chain members, which does not fulfill the actual role of political CSR. Hence, the root causes of the conflict mineral problems are not addressed but rather avoided from a risk management point of view. Interestingly, this analytical approach is strongly prevalent in the automotive industry which is usually very advanced in terms of data availability and maturity of supply chain processes (e.g., Groetsch et al., 2013). Further these firms also claim to be very active in CSR, demonstrating that conflict mineral management is to a certain extent decoupled from their activities, which also shows that proficiency in supply chain management itself rather fuels conflicts in upstream supply chains than solving them. This raises serious doubts about CSR projects of firms which do not tackle major problems related to their business model, but rather concentrate on those topics that do not touch their business model.

Similarly, compliance-driven firms rather pursue SCDD as they are pressured to do so by customer requirements. This often also leads to the avoidance of sourcing conflict minerals from the DRC region. Yet, in both cases these implementation patterns do not really entail responsibilities that traditionally fall within states' spheres of influence. Only in cases in which firms really commit themselves to SCDD by strongly implementing the OECD Guidance, raising awareness for the topic of conflict minerals in general, and by working jointly and collaboratively with NGOs on solving the problems in the region, firms really tend to fill the above mentioned governance gaps and help to address root causes of these problems.

The different patterns of SCDD emergence can partly also be explained by Litz' (1996) model as stimuli influence the direction of implementation patterns of SCDD, also in the case of conflict minerals. Based on our findings, regulative pressure and peer pressure rather lead to analytical and compliance-driven implementation patterns of SCDD, whereas competitive pressure results particularly more often in analytical patterns. This strongly shows that different 
forms of SCDD implementation are influenced by external stimuli. Interestingly however, it is not possible to explain commitment approaches based on these external pressures alone.

Thorough SCDD implementation taking on political CSR roles seems to be represented across sectors and different kinds of stimuli. Yet, our results indicate that smaller firms and firms further up in the supply chain are less likely to dedicate their resources towards a real commitment to SCDD implementation. Hence, the phase of deliberation as per the model of Litz (1996) is strongly influenced by factors internal to the firm such as values, management commitment, etc. This is also in line with the ongoing debate in strategic CSR, which studies how market and competitive considerations influence CSR activities, and how companies strive to reach competitive advantage by combining economic and social/ethical value creation (e.g., Crane et al., 2014; McWilliams et al., 2006). Specifically this also refers to Weaver et al. (1999)'s study in which they show that institutional pressures and internal factors have to fit in order to achieve CSR performance. Especially management commitment and values are important drivers in their study. Along those lines our study shows an important interplay of stimuli perceptions and the deliberate response that influence the pursuit of political CSR.

The last stage of Litz' (1996) model is dedicated to performance outcomes. All firms in our sample, no matter which implementation strategy they pursue, apparently benefit from market performance, whereas short-term financial benefits (e.g., through reduction of risks) play a less important role. Although, based on our explorative approach we can't reliably assess whether these market performance benefits are of significantly different size for the three implementation patterns, so far it seems that all implementation patterns help to improve the image of firms with respect to conflict minerals. This is particularly the case with regard to achieving more goodwill of clients and customers through signaling better reputation. These findings suggest to a certain extent that commitment-based approaches, specifically as they require more committed resources due to the complexity of the task, are not leading to shortterm benefits of firms. However, at the same time this also means that the current system of managing supply chains is set up in a manner, in which root cause problems in DRC will not be addressed as only a small proportion of firms thoroughly take care of these issues. Perhaps, this fact is linked to the circumstance that consumers are not yet familiar with variations in different implementation patterns as well as the novelty of the topic. This is in line with similar problems for other proactive measures of CSR and/or environmental management (e.g., cp. discussions on labels, standards, and certificates, $\mathrm{CO}_{2}$-emission measurement systems, etc.). In this regard, this insight also provides a new nuance to the literature that investigated 
performance effects of CSR where a majority of large scale empirical studies indeed found significant financial effects (for an overview see Orlitzky et al., 2003).

A positive side effect for committed firms comprises relational assets. These relational assets result from networks and structures by collaborative approaches to supply chain management in general. Yet, although there is a vast stream in the literature which has shown that collaborative approaches to supply chain management might render relational rents (e.g., $\mathrm{Fu}$ and Piplani, 2004; Gulati and Sytch, 2007), so far this effect has perhaps been overlooked in conflict mineral management as we could unravel relational considerations only in one case (Engine A). As extracted from the Engine A case, there is a high potential to build new dynamic capabilities through relational SCDD approaches with external partners, which in turn could help to address emerging future (political) CSR issues of a similar kind. Intuitively, conflict minerals are not to be the last commodity in the context of which firms will be required to pursue political CSR. From this perspective, it is interesting that only a very small portion of firms is prepared to learn and prepare systematically for further challenges of a similar kind.

In supply chain management theories and studies there is a still a focus on first tier suppliers and the focal dyad (Tachizawa and Wong, 2014) often resulting in an enormous pressure on the weakest links in the chain. From a SCDD perspective however, it does not suffice to keep such a limited scope but instead to apply multi-tier instruments and procedures that also actively incorporate those Global South suppliers that often have to bear the greatest burden. Consequently, this article is contributing in answering the call for research beyond dyadic buyer-supplier relationships (e.g., Abbasi and Nilsson, 2012) and thereby extending the recently emerging literature on multi-tier supply chain management theories (e.g., Mena et al., 2013; Tachizawa and Wong, 2014). Tachizawa and Wong (2014) already pointed out to four different multi-tier governance mechanisms firms can apply in order to approach topics such as CSR or sustainability that are multi-causal and multi-tier. By identifying three different approaches regarding how SCDD is implemented within corporate practice, we contribute to this existent literature on supply chain governance and their theoretical foundations. Also this literature of multi-tier supply chain management could benefit from interconnecting with literature on political CSR as classical supply chain management instruments fail to address these concerns.

The discussion about chain liability (Hartmann and Moeller, 2014) that emerges from the multi-tier character of supply chains opens up a new dimension of assigning responsibility to companies in contexts, where there is no direct causal relationship between downstream companies and the origin of human rights violations. This raises a lot of interesting questions as the traditional concept of ascribing responsibility is apparently annulled, at least from a 
causal-responsibility point of view, where an actor is responsible for an event, if a) she caused it; b) she acted voluntarily; and c) she has been aware of the consequences associated with her action(s) (Hart, 1968). SCDD and political CSR advocate liability-responsibility in the case of conflict minerals, even though firms might not directly cause these problems. From this perspective, SCDD and other approaches towards political CSR flow into an expansion of responsibilities and even transcend the normative claims of stakeholder theory (Whelan, 2012): Social conflicts that occur in DRC outreach European OEMs' scope of stakeholders - defined as "any group or individual who can affect or is affected by the achievement of the organization's objectives" (Freeman, 1984, p. 46) - since it is questionable that those remote groups have a direct link to the OEMs objectives. As responsibility of firms is originally not included in supply chain concepts it is important to extend supply chain management research accordingly. Not least due to the severe impacts focal firms are able to "cause" in sourcing countries. Hence, not only the multiplicity of intertwined social conflicts, but also the challenge to mitigate these over numerous tiers makes conflict minerals a problem that lies beyond the scope of individual firms' governance systems or compliance regimes (Rotter et al., 2014).

By introducing political CSR further into the context of multi-tier supply chains our study evokes further critical discussion which we will address in three steps, leading to important implications and future research directions also for supply chain management research:

First, power is still underrepresented in the discourse about (political) CSR practices, particularly from a structural perspective (Drebes, 2014). As the analysis has shown, particularly smaller upstream suppliers have fewer incentives to implement SCDD beyond purely analytical implementation patterns and simultaneously fewer resources to do so, resulting in relatively loose coupling. Hence from a power imbalance perspective, it is at least arguable, if strong Western firms are in such a powerful position from which they can directly exploit their suppliers by complying with SCDD mechanisms. As Drebes (2014, p. 7) states: "[...] by acting in certain ways (for example by implementing social standards in factories) they [multinational corporations] exert power over the actions of others ${ }^{2}$, for example their suppliers or the workers in the supplier factories".

Although requirements for SCDD might be acceptable from a purely liberal and businessoriented as well as from a juridical point of view, still fairness considerations are to be considered in supplier exploitation relationships (Schleper et al., 2015). Power imbalances and

\footnotetext{
${ }^{2}$ Drebes' argument is mainly based on Foucault's definition of a relationship of power as "a mode of action which does not act directly and immediately on others. Instead, it acts upon their actions: an action upon an action, on existing actions or on those which may arise in the present or the future" (Foucault, 1982, p. 789).
} 
different degrees of mutual dependencies are prerequisites for exploitative scenarios (Schleper et al., 2015) and far from being equally distributed in corporate practice (Nyaga et al. 2013). In supply chains in which companies from the Global South are involved, these power imbalances are expected to be even stronger as internationally acting companies can easily outsource their 'easy-labor' products to other locations (Drebes, 2014). This exit-option shows structural power differences among corporations in times in which labor is much more immobile than capital (Merk, 2009). Yet, these structural power imbalances are constructions of social interactions and not a given thing and hence could be overcome by better institutional frameworks and changing individuals' and companies' conceptions of these issues. Although some scholars point out that indirect supplier upstream are not directly influenced by the power of large buying firms (cp. Grimm et al., 2011), it is at least questionable if lower-tier suppliers are not directly influenced by the power of large buying firms. Of course, there exists a lack of information and direct control mechanisms which diminishes the direct influence of focal firms. However, taking a critical perspective with regard to power imbalances, it is arguable that between lowertier suppliers in the Global South (i.e., DRC and adjunct regions) and focal firms a mediated power relationship exists. Intermediary frameworks created in Western institutions such as standards, certification processes, International Organizations and other mechanisms (e.g., SCDD) can result in a structural power regime. As these structures and institutions are often controlled by Western actors (e.g., World Trade Organization, World Bank, International Monetary Fund, etc.) they represent to some degree varieties of Western imperialism and hence neocolonialism $^{3}$ (Prasad, 2003; Young, 2001). As a result, these structural power mechanisms allow multinational focal firms to influence their indirect suppliers. Yet as mentioned before, smaller suppliers might not have the potential to absorb the pressure in an appropriate way, resulting in loose coupling reactions with rather analytical implementation patterns of SCDD as well as exploitative situations (Schleper et al., 2015).

Second, ascribing multinational companies a state-like role, as political CSR does, immediately evokes the question of legitimacy of this new role. Regardless of how strong stakeholders' expectations in terms of stakeholder accountability (Parmigiani et al., 2011) or chain liability (Hartmann and Moeller, 2014) may be, first and foremost, focal firms are focusing on their core task which is the management of multitier supply chain networks from a

\footnotetext{
${ }^{3}$ Prasad (2003, p. 6) defines neocolonialism as the "continuation of Western colonialism by nontraditional means" although the former colonies in the Global South are de facto independent. Besides economic and political dimensions of control, these means also include cultural control.
} 
business management perspective and not from a political CSR perspective. This leads to two legitimacy and accountability problems.

On the one hand, stakeholders rarely care about the actual capabilities of these focal firms in collecting reliable and accurate information on their supply chain networks and their influence on other actors in preventing misconduct (Hartmann and Moeller, 2014). Supply chains are built continuously over time with a strong focus on either efficiency or responsiveness (Fine, 2000; Fisher, 1997) and not with a main goal of being sustainable or ethical. Thus, as Gualandris and Pagell (2015) state, there exists an "accountability gap" between stakeholders and focal firms as the latter fall short of keeping pace with accountability expectations of stakeholders.

On the other hand, legitimacy questions arise with regard to the relationships between the new state-like companies and their quasi- governed actors in the Global South (in this case the DRC) (Rotter et al., 2014). This aspect is linked to the power imbalance perspective as described above. Although many different theories and arguments in the literature about political CSR exist on how legitimacy in these relationships can be justified (e.g., Habermasian discourse ethics, institutional theory, or Rawlsian considerations on justice, for a detailed overview see Frynas and Stevens, 2014), still there needs to be the possibility to hear the voices of those that are mainly affected by conflicts as well as potential solutions (i.e., SCDD and other regulative standards). Against the background of discourse ethics and a Rawlsian veil of ignorance, those who are to be governed should have the opportunity of participating in the discourse as equally entitled actors (Mueller et al., 2009). However, these perspective are still severely underrepresented (Banerjee, 2010).

Third, it remains unclear if the real intentions of companies are what they pretend to be, or if at least some of them just act in a mode of paying lip-service. As Rotter et al. (2014) highlight it is questionable if corporate actors really aim at an improvement of human rights conditions within conflict countries. Rather, they could be motivated by legitimacy pressures of local stakeholders or upcoming mimetic reasons due to initiatives like the OECD Guidance. Thus, one should not be too optimistic in terms of enlightened firms that see themselves as substitutes for states or other regulative bodies. As Rotter et al. (2014, p. 597) state "despite the political power they wield, [companies'] identity is still tied to that of a profit-making organization". This leads us directly to a more pragmatic and risk-based view on SCDD.

Besides this normative perspective on the importance of managing conflict minerals, the topic also poses complex risks for firms, particularly for those located downstream supply chains as the analysis with a result of six companies has shown. Yet, Grimm et al. (2011) point 
out that the more upstream the position of a supplier, generally, the more problems are linked to it, at least in terms of CSR and sustainability issues. This is the case due to particularly four inherent aspects: Lower-tier suppliers 1. are not directly influenced by the power of large buying firms, 2. do not provide much information, 3. are less accessible for external stakeholder pressure since they are small, relatively unknown by the public, and operating in countries with low CSR and sustainability standards, and 4. are easier to replace by supply chain partners which significantly lowers their relative importance for larger downstream firms (Tachizawa and Wong, 2014).

Finally, SCDD can be interpreted as a concept that emerged predominantly in the conflict mineral supply chain, but that provides proof that firms realistically can manage conflict mineral supply chains without just stopping to source from certain regions, causing further social issues in the affected regions. SCDD patterns thus inform research also for further commodities as well as for cases where firms produce complex products.

\subsection{Managerial implications}

Exchange with executives emphasized the novelty of the issue of conflict minerals and revealed a misalignment of due diligence practices along the supply chain. Based on our analysis, we propose a robust recommendation for SCDD implementation.

First, downstream companies are usually in a powerful position and are affected by regulation on conflict minerals. In addition, these firms are generally aware of relevant guidance on SCDD implementation. Moreover, they possess the resources to establish or already have in place sophisticated supply chain governance mechanisms. Hence for effective supply chain wide SCDD downstream firms should rely on compliance practices. To facilitate the implementation of compliance practices, downstream firms are suggested to adapt to the commitment pattern: raising and living a culture of collective responsibility and assisting their suppliers in meeting compliance requirements will accelerate the prevalence of SCDD. Above all, for downstream firms the market performance impact of compliance practices will be supplemented by relational impacts of commitment offering mid-term benefits (i.e., strengthened industry relationships). This is particularly true for situations in which the power imbalance within a supply chain network is quite high in favor of the focal firm in Western countries compared to suppliers in the Global South. As previous studies in the field of power relations within supply chain networks have shown, power abuse can have negative effects on 
the powerful actor $^{4}$ (Emerson, 1962; Lawler, 1992; Kim et al., 2005). This might be the case as suppliers become resistant to the pressure of the stronger focal firms and start to behave deceptively and opportunistically in these scenarios. Hence, what is needed is a more critical and fairness-oriented perspective of managers in these strong focal firms towards a "thinking in suppliers' shoes" (Schleper et al., 2015).

Second, first-tier suppliers are either subject to regulation themselves or they receive competitive pressure from customers. Depending on available resources and the maturity of the conflict minerals issue in their organization, component manufacturers should engage either in analytical or compliance practices. In case of developed governance systems and certain awareness on conflict minerals, it is best to fulfill and to pass on requests for compliance. Analytical practices are a valuable avenue for firms that are confronted with compliance requests for the first time. Once they have identified critical products and suppliers, compliance practices are a reasonable supplement.

Third, smelters and refineries are confronted with a high amount of regulative and customer pressures but often lack sufficient resources to fulfill these requests. One remedy would be to outsource compliance measures to downstream funded third party certification organizations (i.e., CFSI), thereby reducing compliance costs upstream but at the same time ensuring reliability of certification. Hence, applying analytical practices is ideal for smelters and refineries. As they usually source unrefined conflict minerals, chemical analyses can verify the geographical origin of respective minerals.

The issue of conflict minerals is exemplary for other upstream CSR issues. For instance, the production of palm oil, soybeans or tropical timber contributes in some areas to environmental conflicts. Similar to conflict minerals, palm oil or soybeans from stubbed rain forests can be mixed with unproblematic or certified batches eliminating any further attempts for back-tracing. In addition, once uncertified tropical timber is built into furniture, it becomes very difficult to trace the origin of each component. Thus, due diligence represents a viable first step for the currently unregulated supply chains of soybeans and palm oil and an alternative to established certification schemes in the timber industry.

Our study provides also strong recommendations to public authorities impacting the legal framework. Exchange with executives suggests that many firms will only undertake rigorous SCDD when they can see a directly quantifiable short-term economic benefit or when they are

\footnotetext{
${ }^{4}$ The most pertinent expression in this regard might be "to use power is to lose it" coined by Bacharach and Lawler (1986).
} 
forced by law to implement these practices. This is particularly true for firms that face low levels of public scrutiny. While proactive actors who attempt to fully commit to the OECD voluntary standards do exist, they benefit only to a certain extent as end consumers do not have sufficient transparency on due diligence practices across firms. We would suggest that the OECD Guidance is a viable option for SCDD to which firms should adhere. However, only legal requirements for compliance can change company behavior on a broader scale. Exceptions do exist in cases where industry consortia jointly change the industry landscape, but these initiatives could also be further enabled through a mandatory OECD Due Diligence standard in the EU.

\subsection{Limitations and further research}

Exploratory research has always limitations that are first of all based on the limited sample size. Despite our effort to collect data across industries, firm sizes, varying stages in the supply chain, our findings are limited to this specific sample. We mainly addressed firms in Europe that might follow the OECD guidance on conflict minerals, but are to a larger extent not forced by law to follow conflict mineral management practices.

Thus, one of the main limitations refers to the above mentioned neocolonial aspect: The question about liability and responsibility in terms of political CSR and conflict minerals is usually linked to one community's reference point - in our case a Western culture perspective. In this regard, an irresponsible act is "either illegal or morally inacceptable to the larger community" (Jones, 1991, p. 367), which suggests a communitarian and thus geographically and cultural limited understanding of responsibility (Schrempf, 2012). In fact, several studies have emphasized that firms' pursued CSR activities are shaped by the domestic institutional political structures and global policies they face (e.g., Detomasi, 2008; Fransen, 2013). However, only few studies have critically highlighted that a more critical and questioning logic needs to be applied in order to uncover and eradicate neocolonial pitfalls, thereby recalibrating relationships that affect the "Global South" in which most of the producers in global supply chains are located (e.g., Drebes, 2014; Munshi and Kurian, 2007). Thus, Drebes (2014, p. 3) argues that "CSR needs to be discussed with a different and non-mainstream theoretical approach". Although we strive to provide a critical view on SCDD practices, the incorporation of especially smaller upstream suppliers from the Global South is needed in future research.

Moreover, findings for US companies with stricter laws, but also for firms from countries where the management of conflict minerals plays a minor role in the public debate might 
therefore differ. We encourage future research to investigate the impact of the cultural and legal impact on sustainability practices, specifically for SCDD practices.

Also we worked in our research to a large extent with perceptual data, even though secondary data was used for triangulation purposes. Due to this fact social responsibility bias might specifically impact the perceived performance impacts. Even though great care was taken we suggest investigating performance impact on the triple bottom line with externally validated data.

Another shortcoming of our study - even though this also provides more focus to the study - is the strong focus on the upstream supply chain. Specifically end consumers were not taken into account in the study design and it would be interesting to test whether SCDD practices impact end consumers' willingness to pay. This could be further combined with experimental manipulations of the origin of the minerals together with different due diligence practices as well as product and supply chain complexity concerns.

Last, other studies have depicted effects of other contingency variables such as power, dependency, distance, or knowledge resources (e.g., Tachizawa and Wong, 2014) that also might be interesting in investigating multi-tier governance mechanism and patterns of implementation of SCDD.

Overall, these shortcomings suggest that theory testing research by the use of survey data or experimental data might pave the way for further explanatory insights on SCDD practices. This research proposes first directions for hypothesis grounded investigations.

\section{Conclusion}

This article is among the first to explore the promotion of CSR into the upstream supply chain by using SCDD. To govern social problems linked to the extraction of and trade with conflict minerals, SCDD represents the most comprehensive approach. In particular, SCDD integrates all relevant supply chain actors into a chain of custody tracking from mine up to the export level until the end consumer interface. As a result, downstream firms are able to verify the origin of conflict minerals and to prevent harmful stakeholder reactions.

However, both conflict minerals and SCDD are novel issues for practice and scholarly research. Thus, our study provides first empirical insights into the implementation of SCDD among the European automotive, aerospace and defense, electronics, technical hardware, and jewelry industry. Our results contribute to the conceptual clarity of SCDD and provide first directions for future theory testing research in the context of conflict minerals and SCDD. 
Additionally, we provide a thorough snapshot of corporate practices, key enablers, and barriers regarding the implementation of SCDD. By grouping the initially dispersed findings into different implementation patterns, we were able to offer recommendations for an effective industry and supply chain wide implementation, thereby enhancing supply chain wide CSR.

Our theoretical contributions are threefold: First, we extend Litz' (1996)s model and show the importance of factors that are internal to the firm (i.g., values) that determine a firm's action to political CSR challenges. Interestingly, firms do not benefit differently in the short run by filling or not filling out their political CSR roles, neither from a market or financial performance perspective. Second, our study provides significant critique of classical supply chain management approaches which do not address CSR issues from a supply perspective from the Global South. In most firms, supply chain management is currently set up to rather avoid the problem of conflict minerals by not sourcing in conflict-laden regions then to address the root causes of these problems. The missing debate as well as the found evidence of poor spread practices such as SCDD raise concerns if CSR approaches rather follow a neocolonial rationale instead of actually pursuing a substantial way to ease conflicts in the Global South. Third, we provide different empirical patterns and antecedents for dealing with the newly discussed chain liability effect, proposing an exploratory model which provides the ground for future theory testing research.

Although there is no one size fits all approach for managing conflict minerals via the use of SCDD, it has become obvious that everyday consumers and firms are affected by the issue of conflict minerals and that there exists an (in-)direct link between us and social problems in conflict areas. Thus, it should also be within the scope of these actors' responsibility to remedy the issues at hand by filling regulative gaps in terms of a more sophisticated (and normative) approach towards political CSR. 


\section{References}

Abbasi, M and Nilsson, F (2012). Themes and Challenges in Making Supply Chains Environmentally Sustainable, Supply Chain Management: An International Journal, Vol. 17, No. 5, pp. 517-530.

Amaeshi, KM, Osuji, OK, and Nnodim, P (2008). Corporate Social Responsibility in Supply Chains of Global Brands: A Boundaryless Responsibility? Clarifications, Exceptions and Implications. Journal of Business Ethics, Vol. 81, No. 1, pp. 223-234.

André, G and Godin, M (2014). Child Labour, Agency and Family Dynamics: The Case of Mining in Katanga (DRC), Childhood, Vol. 21, No. 2, pp. 161-174.

Arnold, DG (2010). Transnational Corporations and the Duty to Respect Basic Human Rights, Business Ethics Quarterly, Vol. 20, No. 3, pp. 371-399.

Bacharach, SB and Lawler EJ (1986). Power Dependence and Power Paradoxes in Bargaining, Negotiation Journal, Vol. 2, No. 2, pp. 167-174.

Banerjee, SB (2010). Governing the Global Corporation: A Critical Perspective, Business Ethics Quarterly, Vol. 20, No.2, pp. 265-274.

Bansal, P (2005). Evolving Sustainably: A Longitudinal Study of Corporate Sustainable Development, Strategic Management Journal, Vol. 26, No. 3, pp. 197-218.

Barney, J (1991). Firm Resources and Sustained Competitive Advantage, Journal of Management, Vol. 17, No. 1, pp. 99-120.

Bhat, BA (2013). Forced Labor of Children in Uzbekistan's Cotton Industry. International Journal on World Peace, Vol. 30, No. 4, pp. 61-85.

Bleischwitz, R, Dittrich, M and Pierdicca, C (2012). Coltan from Central Africa, International Trade and Implications for Any Certification, Resources Policy, Vol. 37, No. 1, pp. 19-29.

Bouslah, K, M'Zali, B, Turcotte, M-F and Kooli, M (2010). The Impact of Forest Certification on Firm Financial Performance in Canada and the U.S, Journal of Business Ethics, Vol. 96, No. 4, pp. 551-572.

BSR (2010). Conflict Minerals and the Democratic Republic of Congo. Available: http://www.bsr.org/reports/BSR_Conflict_Minerals_and_the_DRC.pdf [Accessed 02.01.2015].

Busse, C (2016). Doing Well by Doing Good? The Self-interest of Buying Firms and Sustainable Supply Chain Management, Journal of Supply Chain Management, Vol. 52, No. 2, DOI: $10.1111 /$ jscm. 12096.

Carter, CR, and Jennings, MM (2002). Social Responsibility and Supply Chain Relationships. Transportation Research Part E: Logistics and Transportation Review, Vol. 38, No. 1, 37-52.

Carter, CR, and Jennings, MM (2004). The Role of Purchasing in Corporate Social Responsibility: A Structural Equation Analysis, Journal of Business Logistics, Vol. 25, No. 1, pp. 145-186.

Crane, A (1999). Are you Ethical? Please Tick Yes or No. On Researching Ethics in Business Organizations. Journal of Business Ethics, Vol. 20, No. 3, pp. 237-248.

Crane, A, Matten, D, and Moon, J (2008). Corporations and Citizenship, Cambridge: Cambridge University Press.

Crane, A, Palazzo, G, Spence, LJ, and Matten, D (2014). Contesting the Value of "Creating Shared Value", California Management Review, Vol. 56, No. 2, pp. 130-153.

Dahlsrud, A (2008). How Corporate Social Responsibility is Defined: An Analysis of 37 Definitions. Corporate Social Responsibility and Environmental Management, Vol. 15, No. 1, pp. 1-13. 
Dawkins, J and Lewis, S (2003). CSR in Stakeholder Expectations: And Their Implication for Company Strategy, Journal of Business Ethics, Vol. 44, No. 2/3, pp. 185-193.

Detomasi, DA (2008). The Political Roots of Corporate Social Responsibility, Journal of Business Ethics, Vol. 82, No. 4, pp. 807-819.

DiMaggio, PJ and Powell, WW (1983). The Iron Cage Revisited: Institutional Isomorphism and Collective Rationality in Organizational Fields, American Sociological Review, Vol. No. 2, pp. 147-160.

Dobele, AR, Westberg, K, Steel, M and Flowers, K (2014). An Examination of Corporate Social Responsibility Implementation and Stakeholder Engagement: A Case Study in the Australian Mining Industry, Business Strategy and the Environment, Vol. 23, No. 3, pp. 145-159.

Doorey, DJ (2011). The Transparent Supply Chain: From Resistance to Implementation at Nike and Levi-Strauss, Journal of Business Ethics, Vol. 103, No. 4, pp. 587-603.

Drebes, MJ (2014). Including the 'Other': Power and Postcolonialism as Underrepresented Perspectives in the Discourse on Corporate Social Responsibility, Critical Sociology, DOI: $10.1177 / 0896920513509824$.

Duhigg, C and Barboza, D (2012). In China, Human Costs Are Built into an Ipad. In: New York Times (published January 25, 2012). Available:

http://www.nytimes.com/2012/01/26/business/ieconomy-apples-ipad-and-the-humancosts-for-workers-in-china.html?pagewanted=all\&_r=0 [Accessed February 02, 2015]

Dykstra, DP, Kuru, G, Taylor, R, Nussbaum, R, Magrath, WB and Story, J (2003). Technologies for Wood Tracking: Verifying and Monitoring the Chain of Custody and Legal Compliance in the Timber Industry, Washington D.C.: World Bank.

Eisenhardt, KM (1989). Building Theories from Case Study Research, Academy of Management Review, Vol. 14, No. 4, pp. 532-550.

Emerson, RM (1962). Power-dependency Relations, American Sociological Review, Vol. 27, No. 1, pp. 31-41.

Epstein, MJ and Yuthas, K (2011). Conflict Minerals: Managing an Emerging Supply-Chain Problem, Environmental Quality Management, Vol. 21, No. 2, pp. 13-25.

Escobar, L and Vredenburg, H (2011). Multinational Oil Companies and the Adoption of Sustainable Development: A Resource-Based and Institutional Theory Interpretation of Adoption Heterogeneity, Journal of Business Ethics, Vol. 98, No. 1, pp. 39-65.

European Commission (2014), Regulation of the European Parliament and of the Council Setting up a Union System for Supply Chain Due Diligence Self-Certification of Responsible Importers of Tin, Tantalum and Tungsten, Their Ores, and Gold Originating in Conflict-Affected and High-Risk Areas, Brussels: European Commission.

Fasterling, B and Demuijnck, G (2013). Human Rights in the Void? Due Diligence in the UN Guiding Principles on Business and Human Rights, Journal of Business Ethics, Vol. 116, No. 4, pp. 799-814.

Fine, CH (2000). Clockspeed Based Strategies for Supply Chain Design, Production and Operations Management, Vol. 9, No. 3, pp. 213-221.

Fisher, ML (1997). What is the Right Supply Chain for Your Product?, Harvard Business Review, Vol. 75, pp. 105-117.

Foley, S (2012). Apple Admits It Has a Human Rights Problem. In: The Independent (published February 14, 2012) Available:

http://www.independent.co.uk/news/world/asia/apple-admits-it-has-a-human-rightsproblem-6898617.html [Accessed February 02, 2015].

Foucault, M (1982) The Subject and Power, Critical Inquiry Vol. 8, No. 4, pp. 777-795. 
Fransen, L (2013). The Embeddedness of Responsible Business Practice: Exploring the Interaction Between National-Institutional Environments and Corporate Social Responsibility, Journal of Business Ethics, Vol. 115, No. 2, pp. 213-227.

Freeman, RE (1984). Strategic Management: A Stakeholder Approach. Boston: Pitman. Frynas, G and Stephens, S (2014). Political Corporate Social Responsibility: Reviewing Theories and Setting New Agendas*, International Journal of Management Reviews, DOI: $10.1111 /$ ijmr.12049.

Fu, Y and Piplani, R (2004). Supply-side Collaboration and its Value in Supply Chains, European Journal of Operational Research, Vol. 152, No. 1, pp. 281-288.

Garrett, N and Lintzer, M (2010). Can Katanga's Mining Sector Drive Growth and Development in the DRC?, Journal of Eastern African Studies, Vol. 4, No. 3, pp. 400424.

Gerring, J (2007). Case Study Research: Principles and Practices. Cambridge: Cambridge Univ. Press.

Gibbert, M, Ruigrok, W and Wicki, B (2008). What Passes as a Rigorous Case Study? Strategic Management Journal, Vol. 29, No. 13, pp. 1465-1474.

Global Witness (2011). Global Witness Leaves Kimberley Process, Calls for Diamond Trade to Be Held Accountable [Online]. Available: http://www.globalwitness.org/library/ global-witness-leaves-kimberley-process-calls-diamond-trade-be-held-accountable [Accessed January 19, 2015].

Global Witness (2014). Conflict. Available: http://www.globalwitness.org/campaigns/conflict [Accessed February 02, 2015].

Global Witness (2015). Conflict Minerals in Europe: Stop the EU Supporting a Deadly

Trade (Briefing February 04, 2015). https://www.globalwitness.org/campaigns/ conflictminerals/conflict-minerals-europe-brief/ [Accessed August 01, 2015].

Gold, S, Trautrims, A and Trodd, Z (2015). Modern Slavery Challenges to Supply Chain Management, Supply Chain Management: An International Journal, Vol. 20, No. 5, pp. 485-494.

Griffin, N (2014), Stores Play Down Links to Thai Prawn Slavery Claims. Mail on Sunday (published June 15, 2014), p. 29.

Grimm, JH, Hofstetter, JS, and Sarkis, J (2014). Critical Factors for Sub-Supplier Management: A Sustainable Food Supply Chains Perspective, International Journal of Production Economics, Vol. 152, No. 1, pp. 159-173.

Groetsch, VM, Blome, C, and Schleper, MC (2013). Antecedents of Proactive Supply Chain Risk Management - A Contingency Theory Perspective, International Journal of Production Research, Vol. 51, No. 10, pp. 2842-2867.

Gualandris, J and Pagell, M (2015). Closing the Accountability Gap for Sustainability: The Aid Comes from NGOs and Their Supply Chains, 75th Annual Meeting of Academy of Management (conference proceedings), Available: http://www.researchgate.net/ publication/275716254_Closing_the_accountability_gap_for_sustainability_the_aid_c omes_from_NGOs_and_their_supply_chains [Accessed August 24, 2015].

Gulati, R, \& Sytch, M (2007). Dependence Asymmetry and Joint Dependence in Interorganizational Relationships: Effects of Embeddedness on a Manufacturer's Performance in Procurement Relationships, Administrative Science Quarterly, Vol. 52, No. 1, pp. 32-69.

Hannah, DR (2005). Should I Keep a Secret? The Effects of Trade Secret Protection Procedures on Employees' Obligations to Protect Trade Secrets, Organization Science, Vol. 16, No. 1, pp. 71-84.

Hart, HLA (1968). Punishment and Responsibility, Oxford: Oxford University Press. 
Hartmann, J and Moeller, S (2014). Chain Liability in Multitier Supply Chains?

Responsibility Attributions for Unsustainable Supplier Behavior, Journal of Operations Management, Vol. 32, No. 5, pp. 281-294.

ISO (2007). ISO 2205:2007. Traceability in the Feed and Food Chain - General Principles and Basic Requirements for System Design and Implementation, Geneva: ISO.

ISO (2009). ISO 31000:2009. Risk Management - Principles and Guidelines, Geneva: ISO.

Jaffee, D (2010). Fair Trade Standards, Corporate Participation, and Social Movement Responses in the United States, Journal of Business Ethics, Vol. 92, No. 2, pp. 267285.

Janssen, C, Vanhamme, J, Lindgreen, A, and Lefebvre, A (2014). The Catch-22 of responsible Luxury: Effects of Luxury Product Characteristics on Consumers' Perception of Fit with Corporate Social Responsibility, Journal of Business Ethics, Vol. 119, No. 4, pp. 45-57.

Jennings, PD and Zandbergen, PA (1995). Ecologically Sustainable Organizations: An Institutional Approach, Academy of Management Review, Vol. 20, No. 4, pp. 10151052.

Jones, TM (1991). Ethical Decision Making by Individuals in Organizations: An Issuecontingent Model. Academy of Management Review, Vol. 16 No. 2, pp. 366-395.

Kim, PH, Pinkley, RL, and Fragale, AR (2005). Power Dynamics in Negotiations, Academy of Management Review, Vol. 30, No. 4, pp. 799-822.

Klassen, RD and Vereecke, A (2012). Social Issues in Supply Chains: Capabilities Link Responsibility, Risk (Opportunity), and Performance, International Journal of Production Economics, Vol. 140, No. 1, pp. 103-115.

Kleindorfer, PR and Saad, GH (2005). Managing Disruption Risks in Supply Chains, Production \& Operations Management, Vol. 14, No. 1, pp. 53-68.

Kramer, AE (2010). Philip Morris Said to Benefit from Kazakh Child Labor. In: New York Times (published July 14, 2010). Available:

http://www.nytimes.com/2010/07/14/business/global/14smoke.html?pagewanted=all [Accessed February 02, 2015].

Kristof, ND (2010). Death by Gadget. In: New York Times (published June 26, 2010). Available: http://www.nytimes.com/2010/06/27/opinion/27kristof.html [Accessed February 02, 2015].

Kuhn, A (1963). The Study of Society: A Unified Approach, Homewood, IL: Richard D. Irwin, Inc., and the Dorsey Press, Inc.

Kuhn, A (1974). The Logic of Social Systems, San Francisco: Jossey-Bass.

Lawler, EJ (1992). Power Processes in Bargaining. Sociological Quarterly, Vol. 33, No. 1, pp. 17-34.

LG (2013). LG Electronic's Statement on Conflict Minerals [Online]. Available: http://www.lg.com/global/sustainability/business-partner/conflict-minerals [Accessed November 19, 2014.

Lincoln, YS and Guba, EG (1985). Naturalistic Inquiry, Thousand Oaks: SAGE.

Lindgreen, A and Swaen, V (2010). Corporate Social Responsibility, International Journal of Management Reviews, Vol. 12, No. 1, pp. 1-7.

Lindgreen, A, Swaen, V, and Johnston, WI (2009). Corporate Social Resonsibility: An Empirical Investigation of U.S. Organizations. Journal of Business Ethics, Vol. 85, No. 2, pp. 303-323.

Litz, RA (1996). A Resource-Based-View of the Socially Responsible Firm: Stakeholder Interdependence, Ethical Awareness, and Issue Responsiveness as Strategic Assets, Journal of Business Ethics, Vol. 15, No. 12, pp. 1355-1363. 
Locke, R, Amengual, M, and Mangla, A (2009). Virtue out of Necessity? Compliance, Commitment, and the Improvement of Labor Conditions in Global Supply Chains, Politics \& Society, Vol. 37, No. 3, pp. 319-351.

Locke, RM (2013). Lead Essay: Can Global Brands Create Just Supply Chains, In: Boston Review [Online], Available: http://www.bostonreview.net/forum/can-global-brandscreate-just-supply-chains-richard-locke [Accessed February 03, 2015].

Logsdon, JM and Wood, DJ (2005). Global Business Citizenship and Voluntary Codes of Ethical Conduct. Journal of Business Ethics, Vol. 59, No. 1, p. 55-67.

Manzo, K (2005). Modern Slavery, Global Capitalism \& Deproletarianisation in West Africa. Review of African Political Economy, Vol. 32, No. 106, pp. 521-534.

Matten, D and Crane, A (2005). Corporate Citizenship: Toward an Extended Theoretical Conceptualization, Academy of Management Review, Vol. 30, No. 1, pp. 166-179.

Mäkinen, J and Kourula, A (2012). Pluralism in Political Corporate Social Responsibility, Business Ethics Quarterly, Vol. 22, No. 4, pp. 649-678.

McWilliams, A and Siegel, D (2001). Corporate Social Responsibility: A Theory of the Firm Perspective, Academy of Management Review, Vol. 26, No. 1, pp. 117-127.

McWilliams, A, Siegel, DS, and Wright, PM (2006). Corporate Social Responsibility: Strategic Implications, Journal of Management Studies, Vol. 43, No. 1, pp. 1-18.

Mena, C, Humphries, A, and Choi, TY (2013). Toward a Theory of Multi-tier Supply Chain Management, Journal of Supply Chain Management, Vol. 49, No. 2, pp. 58-77.

Merk, J (2009). Jumping Scale and Bridging Space in the Era of Corporate Social Responsibility: Cross-border Labour Struggles in the Global Garment Industry, Third World Quarterly,Vol. 30, No. 3, pp. 599-615.

Miles, MB and Huberman, AM (1994). Qualitative Data Analysis. An Expanded Sourcebook, Thousand Oaks: SAGE.

Morali, O and Searcy, C (2013). A Review of Sustainable Supply Chain Management Practices in Canada. Berlin/Luxemburg: Springer Science \& Business Media B.V.

Muchlinski, P (2012). Implementing the New UN Corporate Human Rights Framework: Implications for Corporate Law, Governance, and Regulation, Business Ethics Quarterly, Vol. 22, No. 1, pp. 145-177.

Mueller, MV, dos Santos, VG, and Seuring S (2009). The Contribution of Environmental and Social Standards towards Ensuring Legitimacy in Supply Chain Governance, Journal of Business Ethics, Vol. 89, No. 4, pp. 509-523.

Munshi D and Kurian P (2007). The Case of the Subaltern Public - A Postcolonial Investigation of Corporate Social Responsibility's (O)missions. In: May, S, Cheney, G, and Roper, J (eds.), The Debate over Corporate Social Responsibility. Oxford: Oxford University Press, pp. 438-447.

New, S (2010). The Transparent Supply Chain, Harvard Business Review, Vol. 88, No. 10, pp. 76-82.

Nyaga, GN, Lynch, DF, Marshall, D, and Ambrose, E (2013). Power Asymmetry, Adaption and Collaboration in Dyadic Relationships Involving a Powerful Partner, Journal of Supply Chain Management, Vol. 49, No. 3, pp. 42-65.

OECD (2013). OECD Due Diligence Guidance for Responsible Supply Chains of Minerals from Conflict-Affected and High-Risk Areas, Paris and Washington, D.C.: Organisation for Economic Cooperation and Development.

Oliver, C (1991). Strategic Responses to Institutional Processes, Academy of Management Review, Vol. 16, No. 1, pp. 145-179.

Orlitzky, M, Schmidt, FL and Rynes, SL (2003). Corporate Social and Financial Performance: A Meta-Analysis. Organization Studies, Vol. 24, No. 3, pp. 403-441.

Pagell, M and Krause DR (2005). Determining when Mutliple Respondents are Needed in Supply Chain Management Research: The Case of Purchasing and Operations. In: 
Weaver, KM (ed.). A New Vision of Management in the $21^{\text {st }}$ Century. Proceedings of the Academy of Management Conference, 5-10 August, 2005.

Pagell, M and Wu, Z (2009). Building a More Complete Theory of Sustainable Supply Chain Management Using Case Studies of 10 Exemplars, Journal of Supply Chain Management, Vol. 45, No. 2, pp. 37-56.

Panikkar, B and Brugge, D (2007). The Ethical Issues in Uranium Mining Research in the Navajo Nation, Accountability in Research: Policies \& Quality Assurance, Vol. 14, No. 2, pp. 121-153.

Parmar, BL, Freeman, RE, Harrison, JS, Wicks, AC, Purnell, L and De Colle, S (2010). Stakeholder Theory: The State of the Art, The Academy of Management Annals, Vol. 4, No. 1, pp. 403-445.

Parmigiani, A, Klassen, RD, and Russo, MV (2011). Efficiency Meets Accountability: Performance Implications of Supply Chain Configuration, Control, and Capabilities, Journal of Operations Management, Vol. 29, No. 3, pp. 212-223.

Pedersen, ER, and Andersen, M (2006). Safeguarding Corporate Social Rresponsibility (CSR) in Global Supply Chains: How Codes of Conduct are Managed in Buyer-Supplier Relationships, Journal of Public Affairs, Vol 6, No. 3/4, pp. 228-240.

Pedersen, E and Gwozdz, W (2014). From Resistance to Opportunity-Seeking: Strategic Responses to Institutional Pressures for Corporate Social Responsibility in the Nordic Fashion Industry, Journal of Business Ethics, Vol. 119, No. 2, pp. 245-264.

Perry, A (2011). The return of the blood diamond (and we don't mean the movie). Time [Online]. Available: world time.com/2011/12/05/the-return-of-the-blooddiamond-andwe-dont-mean-the-movie/ [Accessed: February 09, 2015].

Prasad, A (2003). The Gaze of the Other: Postcolonial Theory and Organizational Analysis. In: Prasad, A (ed.). Postcolonial Theory and Organizational Analysis: A Critical Engagement, New York: Palgrave Macmillan, pp. 3-46.

Prendergast, J and Lezhnev, S (2009). From Mine to Mobile Phone. The Conflict Minerals Supply Chain (De la Mine au Mobilophone. La Chaîne D'approvisionnement des Minerais du Conflit) [Online]. Available: http://www.commerceresources.com/ i/pdf/Mine_To_Mobile.pdf [Accessed February 02, 2015].

RESOLVE (2010), Tracing a Path Forward: A Study of the Challenges of the Supply Chain for Target Metals Used in Electronics [Online]. Available: http://www.resolv.org/siteeiscm/files/2011/02/Tracing_a_Path_Forward-A_Study_of_the_Challenges_of_the_ Supply_Chain_for_Target_Metals_Used_in_Electronics.pdf [Accessed January 01, 2015].

Reuter, C, Foerstl, K, Hartmann, E and Blome, C (2010). Sustainable Global Supplier Management: The Role of Dynamic Capabilities in Achieving Competitive Advantage, Journal of Supply Chain Management, Vol. 46, No. 2, pp. 45-63.

Rhode, D (2014). The Kimberley Process Is a 'Perfect Cover Story' for Blood Diamonds [Online]. Available: http://www.theguardian.com/sustainable-business/diamondsblood-kimberley-process-mines-ethical [Accessed January 01, 2015].

Rotter, J, Airike, P-E and Mark-Herbert, C (2014). Exploring Political Corporate Social Responsibility in Global Supply Chains, Journal of Business Ethics, Vol. 125, No. 4, pp. 581-599.

Ruggie, J (2008). Protect, Respect and Remedy: A Framework for Business and Human Rights, Innovations: Technology, Governance, Globalization, Vol. 3, No. 2, pp. 189212.

Sarfaty, GA (2015). Shining Light on Global Supply Chains, Harvard International Law Journal, forthcoming. 
Scherer, AG and Palazzo, G (2007). Toward a Political Conception of Corporate Responsibility: Business and Society Seen from a Habermasian Perspective, Academy of Management Review, Vol. 32, No. 4, pp. 1096-1120.

Scherer, AG and Palazzo, G (2011). The New Political Role of Business in a Globalized World: A Review of a New Perspective on CSR and Its Implications for the Firm, Governance, and Democracy, Journal of Management Studies, Vol. 48, No. 4, pp. 899-931.

Schleper, MC and Busse, C (2013). Towards a Standardized Supplier Code of Ethics: Development of a Design Concept based on diffusion of innovation theory, Logistics Research, Vol. 6, No. 4, pp. 187-216.

Schleper, MC, Blome, C and Wuttke, DA (2015). The Dark Side of Buyer Power: Supplier Exploitation and the Role of Ethical Climates, Journal of Business Ethics, DOI: 10.1007/s10551-015-2681-6.

Schrempf, J (2012). The Delimitation of Corporate Social Responsibility: Upstream, Downstream and Historic CSR, Business \& Society, Vol. 51, No. 4, pp. 601-618.

Scott, WR (1987). The Adolescence of Institutional Theory, Administrative Science Quarterly, Vol. 32, No. 4, pp. 493-511.

Seale, C (2000). The Quality of Qualitative Research, London: SAGE.

Sedex (2013). Going Deep-The case for multi-tier transparency [Online]. Available: http://www.sedexglobal.com/wp-content/uploads/2011/06/Sedex-TrasnparencyBriefing-Nov-2013.pdf [Accessed February 09, 2015].

Short, JL and Toffel, MW (2010). Making Self Regulation More than Merely Symbolic: The Critical Role of the Legal Environment, Administrative Science Quarterly, Vol. 55, No. 1, pp. 361-396.

Silva, JF and Jacinto, C (2012). Finding Occupational Accident Patterns in the Extractive Industry Using a Systematic Data Mining Approach, Reliability Engineering \& System Safety, Vol. 108, pp. 108-122.

Sinkin, J and Putney, T (2014). Do's and Don'ts of Due Diligence, Journal of Accountancy, Vol. 217, No. 6, pp. 26-29.

Strauss, AL and Corbin, J (1990). Basics of Qualitative Research: Groundet Theory Procedures and Techniques. Newbury Park, CA: Sage Publications.

Sullivan, D and Atama, N (2010). Digging in: Recent Developments on Conflict Minerals. Enough Project. Available: http://www.enoughproject.org/publications/digging-inconflict-minerals [Accessed February 02, 2015].

Tachizawa, EM and Wong, CY (2014). Towards a Theory of Multi-tier Sustainable Supply Chains: A Systematic Literature Review, Supply Chain Management: An International Journal, Vol. 19, No. 5/6, pp. 643-663.

Teece, DJ (2012). Dynamic Capabilities: Routines Versus Entrepreneurial Action, Journal of Management Studies, Vol. 49, No. 8, pp. 1395-1401.

Walsh, JP (2005). Book Review Essay: Taking Stock of Stakeholder Management, Academy of Management Review, Vol. 30, No. 2, pp. 426-438.

Weaver, GR, Treviño, LK, and Cochran, PL (1999). Integrated and Decoupled Corporate Social Performance: Management Commitments, External Pressures, and Corporate Ethics Practices, Academy of Management Journal, Vol. 42, No. 5, pp. 539-552.

Whelan, G (2012). The Political Perspective of Corporate Social Responsibility: A Critical Research Agenda, Business Ethics Quarterly, Vol. 22, No. 4, pp. 709-737.

Working Group on the issue of human rights and transnational corporations and other business enterprises (2014). Human rights and transnational corporations and other business enterprise - Report to the United Nations General Assembly, Available: http://www.ohchr.org/Documents/Issues/SRMigrants/ConsultationRecruitment/Nation alActionPlansOnBusinessAndHR.pdf [Accessed February 02, 2015]. 
Wright C and Bwabizambuga, A (2006) Intituational Pressures, Corporate Reputation, and Voluntary Codes of Conduct: An Examination of the Equator Principles. Business \& Society. Vol. 111, No. 1, pp. 89 - 117.

$\mathrm{Xu}, \mathrm{K}$ and Li, W (2013). An Ethical Stakeholder Approach to Crisis Communication: A Case Study of Foxconn's 2010 Employee Suicide Crisis, Journal of Business Ethics, Vol. 117, No. 2, pp. 371-386.

Yin, RK (1981). The Case Study Crisis: Some Answers, Administrative Science Quarterly, Vol. 26, No. 1, pp. 58-65.

Yin, RK (2014) Case Study Research: Design and Methods, London: SAGE.

Young, R (2001). Postcolonialism: An Historical Introdcution. Oxford: Blackwell Publishers. Young, SB, Fonseca, A and Dias, G (2014). Principles for Responsible Metals Supply to Electronics, Social Responsibility Journal, Vol. 6, No. 1, pp. 126-142. 


\section{Tables \& Figures}

Table 1: Existing practices to increase transparency along supply chains

\begin{tabular}{|c|c|}
\hline Practice & Approach, Focus, and Risk Perception \\
\hline Certification & $\begin{array}{l}\text { Approach: Assessment of corporate processes and production conditions (i.e., self-, } \\
\text { second- or third party audit) against specific standards (e.g., UTZ, Fair Trade label, } \\
\text { Kimberley Process certificate) } \\
\text { Focus: Single firm } \\
\text { Risk perception: Adherence to issues stated in specific standard's catalogue }\end{array}$ \\
\hline Chain of Custody & $\begin{array}{l}\text { Approach: Assessment of corporate processes and production conditions at every } \\
\text { company with financial ownership of the respective product to establish certified chain } \\
\text { (e.g., Forest Stewardship Council, Marine Stewardship Council) } \\
\text { Focus: Entire value chain } \\
\text { Risk perception: Adherence to issues stated in specific standard's catalogue }\end{array}$ \\
\hline Traceability & $\begin{array}{l}\text { Approach: Following the physical movement of materials through specific stages of } \\
\text { production, processing, and distribution } \\
\text { Focus: Materials } \\
\text { Risk perception: Product / materials not meeting quality requirements }\end{array}$ \\
\hline Due Diligence & $\begin{array}{l}\text { Approach: Gathering of internal and external information and gaining a sound } \\
\text { knowledge of the company, its industry, financial condition, customers, competitors, } \\
\text { suppliers, business processes, technology and, above all, management; sharing relevant } \\
\text { upstream information with downstream partners } \\
\text { Focus: Single firm } \\
\text { Risk perception: Adherence to regulatory and/or voluntary requirements }\end{array}$ \\
\hline
\end{tabular}

Table 2: Validity measures

\begin{tabular}{|c|c|c|c|c|}
\hline \multirow{2}{*}{$\begin{array}{l}\text { Validity/ } \\
\text { Reliability } \\
\text { Criterion }\end{array}$} & \multicolumn{4}{|c|}{ Research Phase } \\
\hline & Design & Case Selection & Data Gathering & Data Analysis \\
\hline $\begin{array}{l}\text { Construct } \\
\text { Validity }\end{array}$ & $\begin{array}{l}\text { Questions built on } \\
\text { research } \\
\text { framework }\end{array}$ & NA & $\begin{array}{l}\text { Multiple sources of } \\
\text { information } \\
\text { Multiple interviewers }\end{array}$ & $\begin{array}{l}\text { Data triangulation } \\
\text { based on } \\
\text { independent } \\
\text { sources }\end{array}$ \\
\hline $\begin{array}{l}\text { Internal } \\
\text { Validity }\end{array}$ & $\begin{array}{l}\text { Theoretical } \\
\text { framework }\end{array}$ & NA & $\begin{array}{l}\text { Most knowledgeable } \\
\text { respondents for } \\
\text { conflict minerals } \\
\text { and SCDD } \\
\text { interviewed }\end{array}$ & $\begin{array}{c}\text { Pattern matching } \\
\text { among cases }\end{array}$ \\
\hline $\begin{array}{l}\text { External } \\
\text { Validity }\end{array}$ & $\begin{array}{l}\text { Description of } \\
\text { sampling criteria }\end{array}$ & $\begin{array}{l}\text { Precise description of } \\
\text { case firms, } \\
\text { context, and } \\
\text { situation }\end{array}$ & NA & NA \\
\hline Reliability & $\begin{array}{l}\text { Develop case study } \\
\text { protocol } \\
\text { Develop case study } \\
\text { data set }\end{array}$ & $\begin{array}{l}\text { Selection within EU } \\
\text { Selection including } \\
\text { most relevant } \\
\text { actors }\end{array}$ & $\begin{array}{l}\text { Transcription of all } \\
\text { interviews by } \\
\text { interviewers } \\
\text { Semi-structured } \\
\text { interview guidelines }\end{array}$ & $\begin{array}{l}\text { Involvement of } \\
\text { authors who did not } \\
\text { gather data } \\
\text { Convergence of } \\
\text { interpretations }\end{array}$ \\
\hline
\end{tabular}


Table 3: Participating organizations.

\begin{tabular}{|c|c|c|c|c|c|}
\hline Company & $\begin{array}{l}\text { Industrial } \\
\text { Sector }\end{array}$ & Size & Turnover & $\begin{array}{l}\text { Supply Chain } \\
\text { Position }\end{array}$ & $\begin{array}{l}\text { Department of } \\
\text { Interviewee }\end{array}$ \\
\hline Auto A & Automotive & Large & $>$ EUR 60bn & $\begin{array}{l}\text { Component } \\
\text { Manufacturer }\end{array}$ & $\begin{array}{l}\text { Purchasing, CSR and } \\
\text { Conflict Minerals }\end{array}$ \\
\hline Auto B & Automotive & Large & $>$ EUR 10bn & $\begin{array}{l}\text { Component } \\
\text { Manufacturer }\end{array}$ & Logistics and Quality \\
\hline Auto C & Automotive & Large & $>$ EUR 10bn & OEM & Corporate Sustainability \\
\hline Auto D & Automotive & Large & $>$ EUR 20bn & OEM & $\begin{array}{l}\text { Purchasing Risk and } \\
\text { Supply Chain } \\
\text { Sustainability }\end{array}$ \\
\hline Auto E & Automotive & Large & $>$ EUR 50bn & OEM & $\begin{array}{l}\text { Environment, Energy and } \\
\text { Strategic Raw Materials }\end{array}$ \\
\hline Auto F & Automotive & Small & $>$ EUR 10m & Trader & CEO \\
\hline Aero A & $\begin{array}{l}\text { Aerospace/ } \\
\text { Defense }\end{array}$ & Large & $>$ EUR 10bn & OEM & Purchasing and Logistics \\
\hline Aero B & $\begin{array}{l}\text { Aerospace/ } \\
\text { Defense }\end{array}$ & Small & $>$ EUR 10m & $\begin{array}{l}\text { Component } \\
\text { Manufacturer }\end{array}$ & Purchasing \\
\hline Aero C & $\begin{array}{l}\text { Aerospace/ } \\
\text { Defense }\end{array}$ & Large & $>$ EUR 50bn & OEM & $\begin{array}{l}\text { Sustainability, } \\
\text { Environment and CSR }\end{array}$ \\
\hline Aero D & $\begin{array}{l}\text { Aerospace/ } \\
\text { Defense }\end{array}$ & Medium & $>$ EUR 20m & Trader & $\mathrm{CEO}$ \\
\hline Electro A & Electronics & Large & $>$ EUR 80bn & OEM & Conflict Minerals \\
\hline Electro B & Electronics & Large & > EUR 30bn & OEM & Conflict Minerals \\
\hline & & & & & Supplier Sustainability \\
\hline Electro C & Electronics & Large & $>$ EUR 20bn & OEM & CSR and Purchasing \\
\hline Electro D & Electronics & Large & $>$ EUR 200m & $\begin{array}{l}\text { Component } \\
\text { Manufacturer }\end{array}$ & Purchasing \\
\hline Electro $\mathbf{E}$ & Electronics & Large & $>$ EUR 400m & $\begin{array}{l}\text { Component } \\
\text { Manufacturer }\end{array}$ & Procurement \\
\hline Electro F & Electronics & Small & $>$ EUR $15 \mathrm{~m}$ & Trader & CEO \\
\hline Engine A & Engineering & Large & $>$ EUR 5bn & OEM & Corporate Risk \\
\hline Engine B & Engineering & Small & $>$ EUR 10m & OEM & Production \\
\hline Engine $\mathrm{C}$ & Engineering & Large & $>$ EUR 5bn & OEM & Environment \\
\hline Engine D & Engineering & Large & $>$ EUR 300m & OEM & Information Security \\
\hline Engine $\mathbf{E}$ & Engineering & Large & $>$ EUR 500m & $\begin{array}{l}\text { Component } \\
\text { Manufacturer }\end{array}$ & Sustainability \\
\hline Engine F & Engineering & Small & $>$ EUR 10m & Smelter & Tantalum Procurement \\
\hline Jewel A & Jewelry & Large & $>$ EUR 80m & OEM & $\begin{array}{l}\text { Diamond and Gold } \\
\text { Purchasing }\end{array}$ \\
\hline Jewel B & Jewelry & Large & $>$ EUR 5bn & OEM & Corporate Affairs \\
\hline Jewel C & Jewelry & Small & $>$ EUR $10 \mathrm{~m}$ & $\begin{array}{l}\text { Component } \\
\text { Manufacturer }\end{array}$ & $\mathrm{CEO}$ \\
\hline Jewel D & Jewelry & Medium & $>$ EUR 200m & Refinery & $\begin{array}{l}\text { Accreditations and } \\
\text { Management Systems }\end{array}$ \\
\hline Jewel E & Jewelry & Large & $>$ EUR 20bn & Refinery & Commercial Director \\
\hline
\end{tabular}


Table 4: Implementation patterns and founding practices

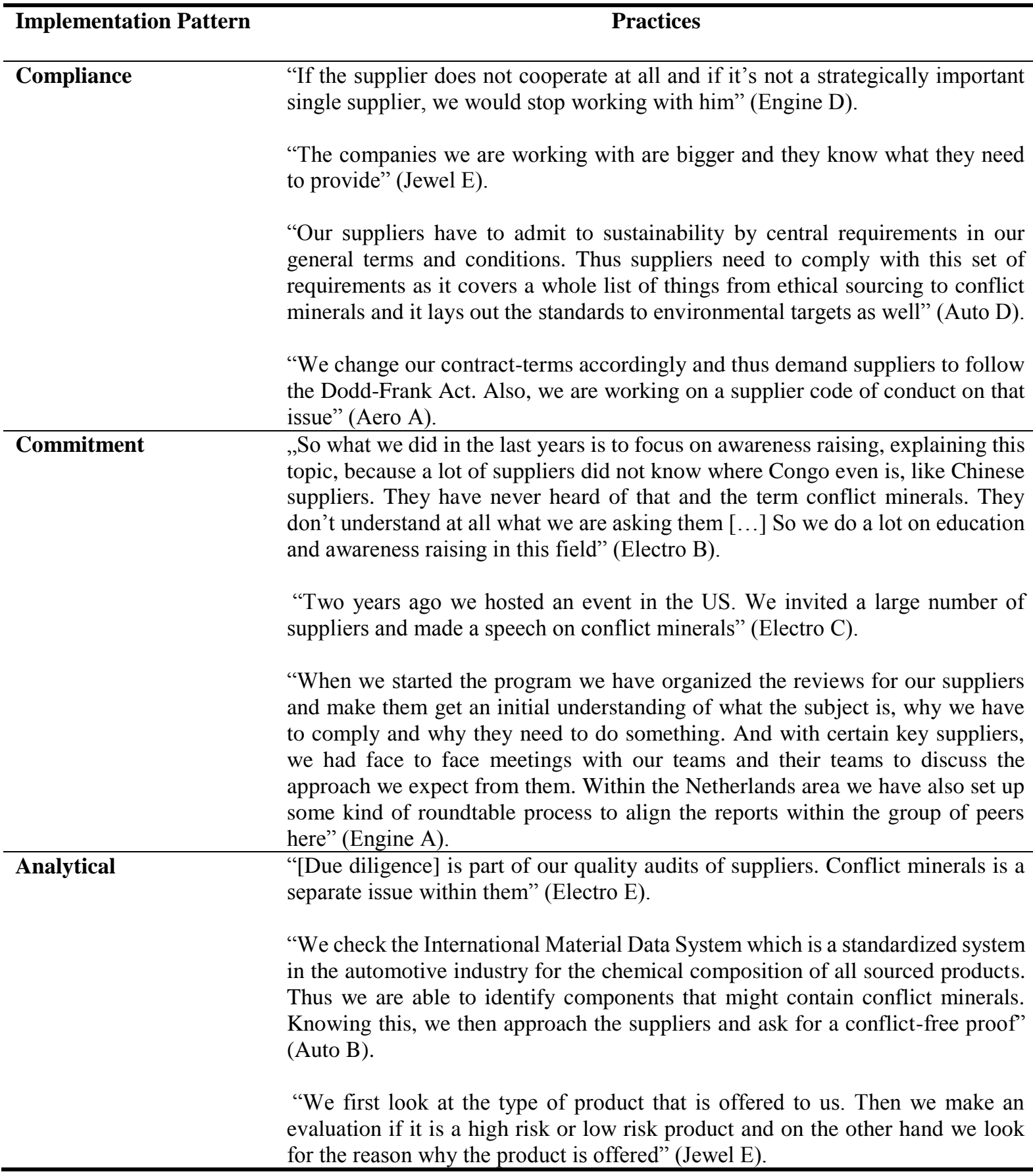


Table 5: Implementation patterns of SCDD

\begin{tabular}{|c|c|c|c|}
\hline \multirow[t]{15}{*}{ Implementation Pattern } & Compliance & Commitment & Analytical \\
\hline & Aero A & Auto A & Aero D \\
\hline & Aero B & Electro B & Auto B \\
\hline & Aero C & Electro C & Auto C \\
\hline & Auto D & Engine A & Auto F \\
\hline & Auto E & & Electro E \\
\hline & Electro A & & Engine $\mathrm{F}$ \\
\hline & Electro D & & Jewel A \\
\hline & Electro F & & Jewel D \\
\hline & Engine B & & Jewel E \\
\hline & Engine $\mathrm{C}$ & & \\
\hline & Engine D & & \\
\hline & Engine $\mathrm{E}$ & & \\
\hline & Jewel B & & \\
\hline & Jewel C & & \\
\hline
\end{tabular}

Table 6: Stimulus for awareness on conflict minerals

\begin{tabular}{|c|c|c|c|}
\hline \multirow[t]{15}{*}{ Stimulus } & Regulative & Peer Pressure & Competitive \\
\hline & Aero A & Electro C & Aero C \\
\hline & Aero B & Engine B & Aero D \\
\hline & Auto B & Engine $\mathrm{C}$ & Auto A \\
\hline & Auto D & Jewel A & Auto C \\
\hline & Auto E & Jewel C & Electro B \\
\hline & Auto F & Jewel D & Electro F \\
\hline & Electro A & & Engine $\mathrm{F}$ \\
\hline & Electro D & & \\
\hline & Electro E & & \\
\hline & Engine A & & \\
\hline & Engine D & & \\
\hline & Engine $\mathrm{E}$ & & \\
\hline & Jewel B & & \\
\hline & Jewel E & & \\
\hline
\end{tabular}


Table 7: Stimulus implementation pattern link

\begin{tabular}{|c|c|c|c|}
\hline Implementation Pattern & Compliance & Commitment & Analytical \\
\hline \multicolumn{4}{|l|}{ Stimulus } \\
\hline \multirow[t]{9}{*}{ Regulative } & Aero A & Engine A & Auto B \\
\hline & Aero B & - & Auto F \\
\hline & Auto D & - & Electro E \\
\hline & Auto E & - & Jewel E \\
\hline & Electro A & - & - \\
\hline & Electro D & - & - \\
\hline & Engine D & - & - \\
\hline & Engine E & - & - \\
\hline & Jewel B & - & - \\
\hline \multirow[t]{3}{*}{ Peer Pressure } & Engine B & Electro C & Jewel A \\
\hline & Jewel C & - & Jewel D \\
\hline & Engine $\mathrm{C}$ & - & - \\
\hline \multirow[t]{4}{*}{ Competitive } & Aero C & Electro B & Aero D \\
\hline & Electro F & Auto A & Auto A \\
\hline & - & - & Auto C \\
\hline & - & - & Engine F \\
\hline
\end{tabular}

Table 8: Expected impact of SCDD

\begin{tabular}{llcc}
\hline Expected Impact & Market & Relational & Financial \\
\cline { 2 - 3 } & Aero A & Engine A & Aero B \\
\cline { 2 - 3 } & Aero D & - & Aero C \\
\cline { 2 - 3 } & Auto A & - & Auto C \\
\cline { 2 - 3 } & Auto B & - & Auto D \\
\cline { 2 - 3 } & Auto E & - & Electro C \\
\cline { 2 - 3 } & Auto F & - & Engine B \\
\cline { 2 - 3 } & Electro A & Engine C \\
\cline { 2 - 3 } & Electro D & - & Engine D \\
\hline & Electro E & - & - \\
\hline & Electro F & - & - \\
\hline & Engine E & - & - \\
\hline & Engine F & - & - \\
\hline & Jewel A & - & - \\
\hline & Jewel B & - & - \\
\hline
\end{tabular}


Table 9: Implementation pattern impact link

\begin{tabular}{|c|c|c|c|}
\hline Impact & $\begin{array}{c}\text { Market } \\
\text { Performance }\end{array}$ & Relational Assets & $\begin{array}{c}\text { Financial } \\
\text { Performance }\end{array}$ \\
\hline \multicolumn{4}{|l|}{ Implementation Pattern } \\
\hline \multirow[t]{8}{*}{ Compliance } & Aero A & - & Aero B \\
\hline & Auto E & - & Aero C \\
\hline & Electro A & - & Auto D \\
\hline & Electro D & - & Engine B \\
\hline & Electro F & - & Engine $\mathrm{C}$ \\
\hline & Engine E & - & Engine D \\
\hline & Jewel B & - & - \\
\hline & Jewel C & - & - \\
\hline \multirow[t]{2}{*}{ Commitment } & Auto A & Engine A & Electro C \\
\hline & Electro B & - & - \\
\hline \multirow[t]{8}{*}{ Analytical } & Aero D & - & Auto C \\
\hline & Auto B & - & - \\
\hline & Auto F & - & - \\
\hline & Electro E & - & - \\
\hline & Engine $\mathrm{F}$ & - & - \\
\hline & Jewel A & - & - \\
\hline & Jewel D & - & - \\
\hline & Jewel E & - & - \\
\hline
\end{tabular}


Table 10: Enablers of SCDD implementation

\begin{tabular}{|c|c|}
\hline Enabler & Dimension \\
\hline \multirow[t]{3}{*}{$\begin{array}{l}\text { External Tools and } \\
\text { Support Systems }\end{array}$} & $\begin{array}{l}\text { "We use the tools and programs that have been developed by the CFSI including } \\
\text { the conflict minerals reporting template and the resource of the conflict smelter } \\
\text { audits [...] We rely on the conflict smelters program for independent third party } \\
\text { audits. We are not performing such audits ourselves - we rely on the reports of } \\
\text { the CFSI program" (Electro B). }\end{array}$ \\
\hline & $\begin{array}{l}\text { "We use the IMDS to track where conflict minerals may originate from. } \\
\text { Applying the IMDS, we can track the specific materials which may contain } \\
\text { conflict minerals and the responsible supplier" (Auto B). }\end{array}$ \\
\hline & $\begin{array}{l}\text { "We have a license on business intelligence tools, to gather information. Well, at } \\
\text { the moment we have developed internal tools but maybe in the future we ought } \\
\text { to buy or develop new systems" (Jewel D). }\end{array}$ \\
\hline $\begin{array}{l}\text { Internal Management } \\
\text { Support }\end{array}$ & $\begin{array}{l}\text { "This is the mission of the company, in a clear statement from our board, from } \\
\text { the CEO [...] The key factor is the awareness of the people, and training of all } \\
\text { people involved in the operations" (Jewel D). }\end{array}$ \\
\hline \multirow[t]{5}{*}{ Power and Trust } & $\begin{array}{l}\text { „How much pressure can our small firm apply? You may find a different answer } \\
\text { at Apple or Intel. But we are a small OEM and we cannot exert sufficient pressure. } \\
\text { [...] And even our suppliers are small firms incapable of passing on requirements } \\
\text { and pressure upstream” (Engine D). }\end{array}$ \\
\hline & $\begin{array}{l}\text { "This is a topic which we only have indirect influence on }[\ldots] \text { the leverage is } \\
\text { clearly in the upstream area. The only thing we can do is to decide whether to } \\
\text { source conflict free or not. We are sitting in the passenger seat - we cannot drive } \\
\text { a strict policy" (Electro A). }\end{array}$ \\
\hline & $\begin{array}{l}\text { "It's quite difficult to put pressure because we are putting a lot of pressure on the } \\
\text { suppliers and sometimes we are putting too much pressure" (Auto E). }\end{array}$ \\
\hline & $\begin{array}{l}\text { "Our traders are our trade secret. Usually you don't tell anybody who is your } \\
\text { supplier. If I ask my supplier who is or please tell us where you buy things some } \\
\text { of them do and some of them say no, that's part of our secret. Like in gold you } \\
\text { have a secret alloy" (Jewel C). }\end{array}$ \\
\hline & $\begin{array}{l}\text { "The IMDS database was accepted by the supplier on one condition: that we don't } \\
\text { have the right to use this information for negotiation purposes. So this is a huge } \\
\text { effort coming from the suppliers to declare the natural content of the parts. So this } \\
\text { database was implemented at the very beginning to make it possible to better track } \\
\text { the rich materials" (Auto E). }\end{array}$ \\
\hline
\end{tabular}


Table 11: Barriers of SCDD implementation

\begin{tabular}{ll}
\hline Barrier & \multicolumn{1}{c}{ Dimension } \\
\hline $\begin{array}{l}\text { Gap in Regulation } \\
\text { Framework }\end{array}$ & $\begin{array}{l}\text { "The biggest challenge is in the uncertainty about what is defined as 'reasonable } \\
\text { effort'. So that's where the challenge would be - also in complying to these } \\
\text { guidelines but also at later stage to show to externals that you indeed engage your } \\
\text { supply chain with a reasonable effort in implementing this guidance" (Engine A). }\end{array}$
\end{tabular}

"The big challenge there is that the smelters don't publish data on that. About 70 percent - especially in Asia - are not in the direct scope of any European or American legislation and I think a key success factor would be to engage the smelters also in the mainly Asian countries and probably you would need the cooperation with the local governments there" (Electro B).

"The fundamental problem of supply chain due diligence is that regulators take a static supply chain for granted" (Auto A).

Market Structure "We are very much depended on these components and then have a problem if these would suddenly be zero. I say there are a few suppliers that could be critical, we sometimes buy customer specific components but if we drop one of those suppliers it could be quite costly because we have to change the products" (Engine E).

"There are currently too few certified smelters that would enable a firm of our size to source totally conflict-free" (Electro A).

Complexity "We are a downstream firm with highly complex products. Thus we do not have an analytical fingerprint of the origin of each mineral contained. [...] There are still nine to eleven tiers between our direct suppliers and smelters. Mapping that would be an extremely costly Chinese whisper- like process" (Electro A).

"But in components, we are far far far from the raw material and of course you know the inquiry is more complicated when more companies are involved" (Electro D).

"It's a complex system because we are a complex metal refiner and it would be much easier if there would be a primary smelter trading about 5 or 10 different concentrates from 5 or 10 different mines. You would have to assess 5 mines and it would be enough but we get materials from everywhere" (Jewel D).

"You end up in other industries, such as metals, electronics, manufacturing, and again if you go through these industries you struggle to get to the level of smelters. This may be 6th or 7th tier, which is very far away to investigate at the moment especially in terms of the automotive industry its exceptionally close to the electronics industry" (Auto D).

Resources and Costs "Extensive upstream-certification requires huge efforts and still would not be achievable due to missing mechanisms in the sourcing regions" (Electro A).

"What we get depends very much on the staff of the supplier. Some are very poor, some are much more comprehensive" (Auto C).

"To say it more drastically, most entrepreneurs in the jewels trade they have no higher education, they are craftsmen, they are designers. And when you confront them with the daily business and ask them to comply with these standards, they don't have the professional background to do it and they don't have the time" (Jewel C).

„Actually we have to deal a lot with paperwork, which is necessary, at least some of them. But we are a small team, two people and you can imagine the administration has increased 10 times. ... We are basically a small trading unit who is unable to do it themselves" (Aero D). 


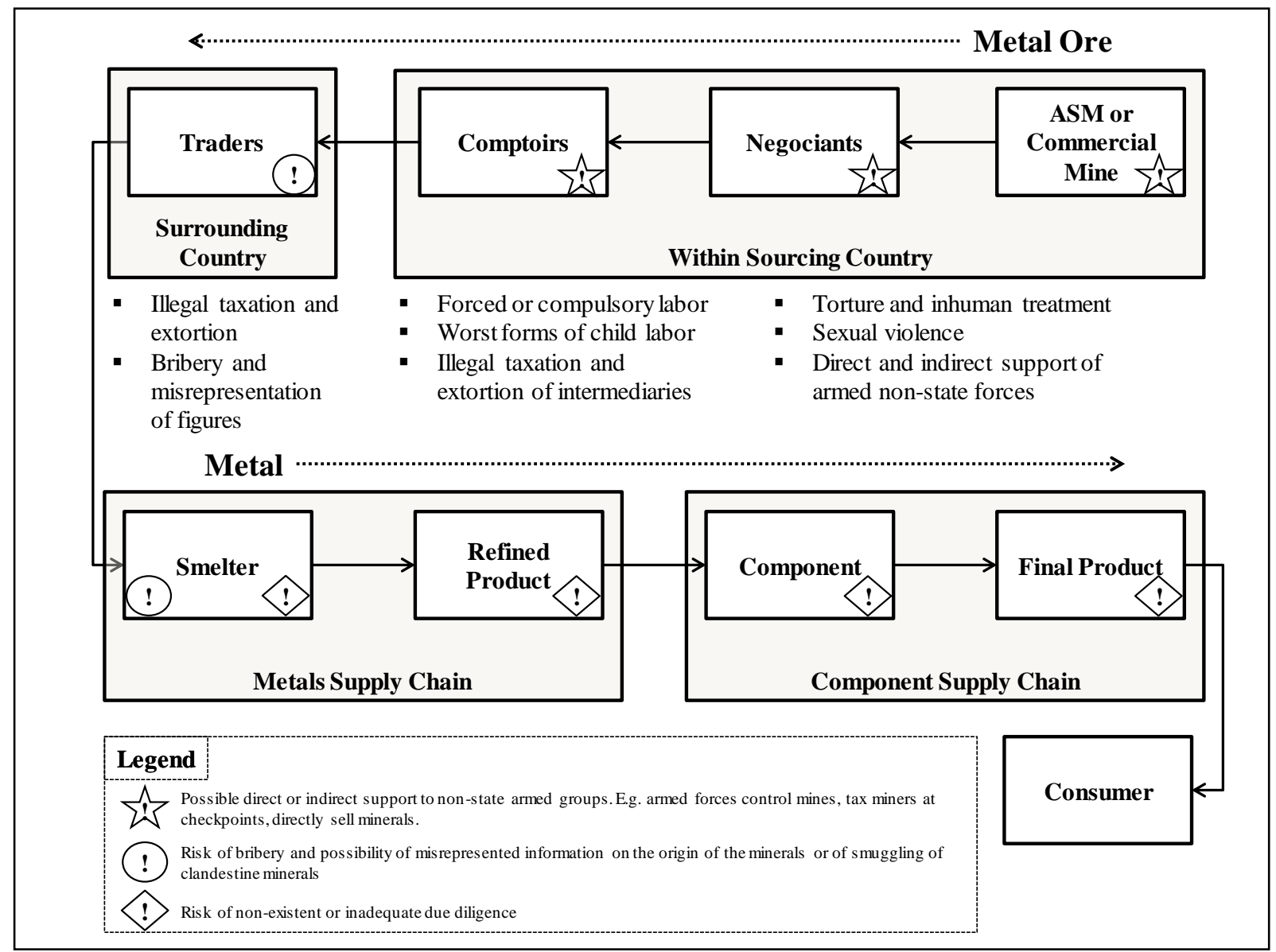

Figure 1: Social conflicts in mineral supply chains. Own illustration based on (OECD, 2013; RESOLVE, 2010)

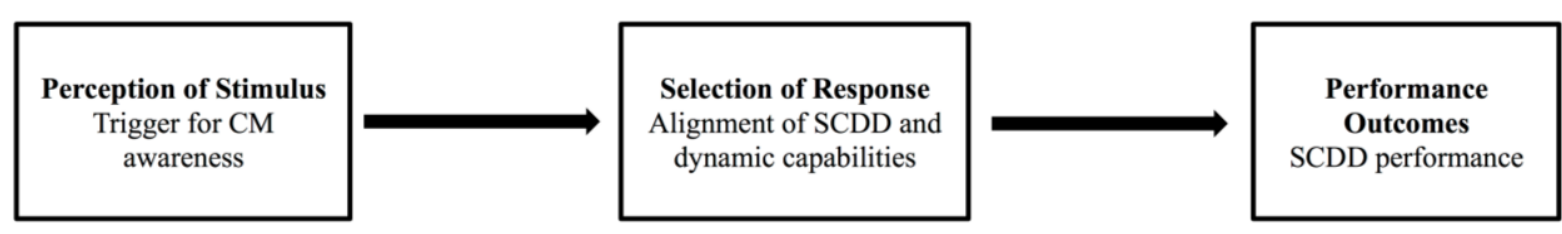

Figure 2: SCDD implementation based on Litz (1996) 


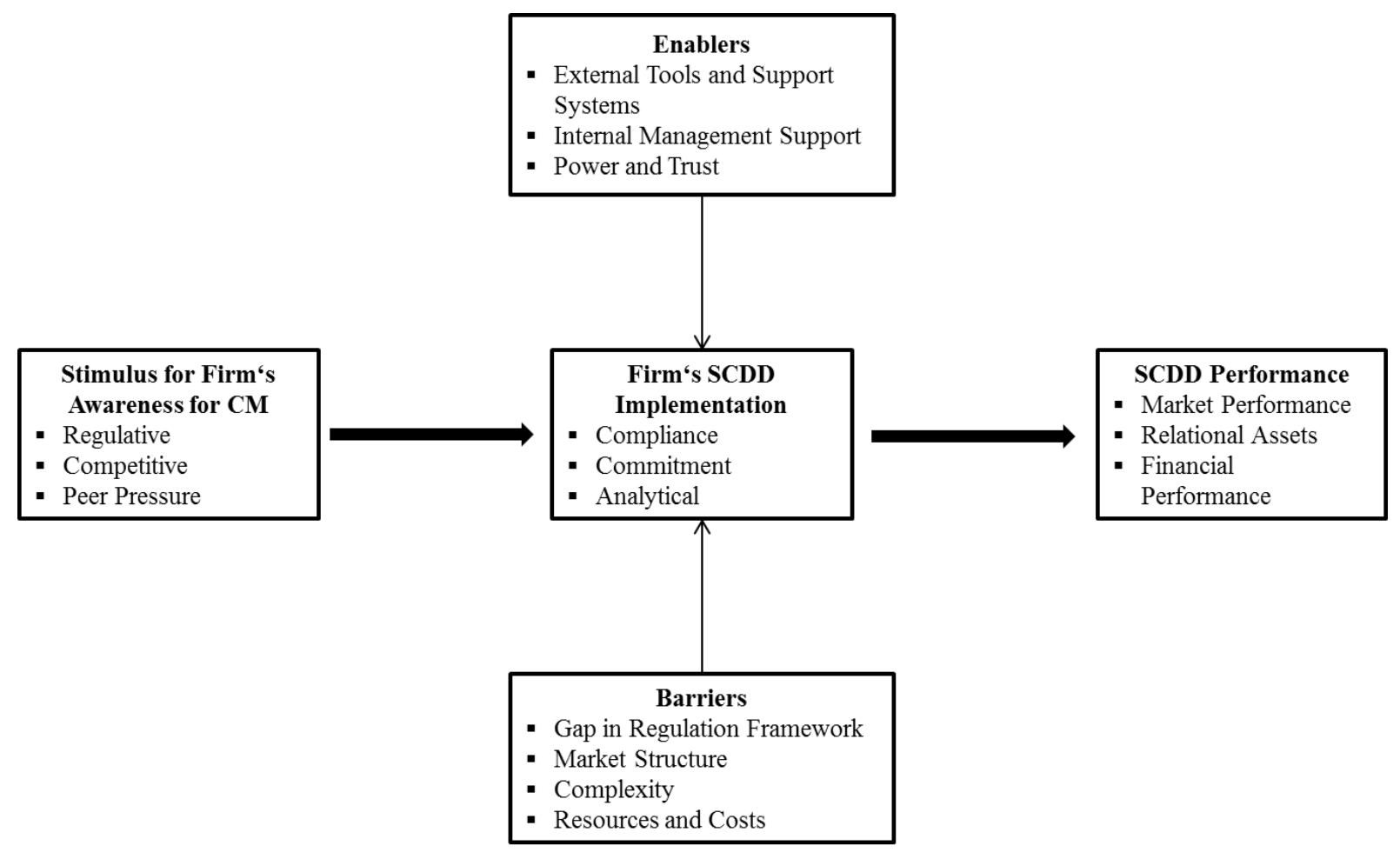

Figure 3: Implementation of SCDD in supply chains for conflict minerals 